Authors Accepted Version: Published as Sturdy Colls, C. 2012. 'Holocaust Archaeology: Archaeological Approaches to Landscapes of Nazi Genocide and Persecution, Journal of Conflict archaeology 7(2): 70-104

\title{
Holocaust Archaeology: Archaeological Approaches to Landscapes of Nazi Genocide and Persecution
}

\author{
Caroline Sturdy Colls
}

Forensic and Crime Science, Faculty of Sciences, Staffordshire University, $U K$

Debate concerning the events of the Holocaust is well embedded in the historical discourse and, thus, clearly defined narratives of this period exist. However, in most European countries the Holocaust has only recently begun to be considered in terms of its surviving archaeological remains and landscapes, and the majority of known sites are still ill-defined and only partially understood from both spatial structural points of view. Additionally, thousands of sites across Europe remain unmarked, whilst the locations of others have been forgotten altogether. Such a situation has arisen as a result of a number of political, social, ethical, and religious factors which, coupled with the scale of the crimes, has often inhibited systematic search. This paper details the subsequent development and application of a non-invasive archaeological methodology aimed at rectifying this situation and presents a case for the establishment of Holocaust archaeology as a sub-discipline of conflict studies. In particular, the importance of moving away from the notion that the presence of historical sources precludes the need for the collection of physical evidence is stressed, and the humanitarian, scientific, academic, and commemorative value of exploring this period is

considered.

Keywords Holocaust, death camps, Treblinka, Halacha Law, Holocaust landscapes project, geophysical survey, forensic archaeology, mass graves

\section{Introduction}

'I have buried this among the ashes where people will certainly dig to find the traces of millions of men who were exterminated'. (Salmon Gradowski, undated in Bezwinska, 1973: 75)

History now records that the Holocaust was a European-wide event that affected, and continues to affect, the lives of countless individuals across the world. The atrocities perpetrated by the Nazis and their Occupation of Europe resulted in the deaths of over eleven million people and irreversibly 
altered the geographic, political, and demographic map of the world. Debate over these events is well embedded in the historical discourse, with a multitude of texts focusing on the nature of the Final Solution, Nazi political and social policy, and in particular assessing the scale of, and responsibility for, genocide in this period. However, whilst the historical events have received considerable attention, in most European countries the Holocaust has only recently begun to be considered in terms of its surviving archaeological remains and landscapes. Whilst there have been attempts to examine some of the extermination and concentration camps, many of the archaeological remnants of this period remain ill-defined, unrecorded, and even, in some cases, unlocated. As time since these events passes, the former prisoners pass away and fewer people live who can feel a tangible and direct connection to this aspect of the past, the risk that these sites will remain unmarked and become increasingly forgotten or dilapidated increases.

Conversely, forensic and conflict archaeologists have cemented the investigation of other genocides into their disciplines; the involvement of forensic archaeologists in mass-grave investigations has ensured that victims of modern genocides are afforded what the United Nations have termed 'basic dignity', whilst conflict archaeologists have conducted significant work with regards the First World War, the Spanish Civil War, and other massacres of the early twentieth century (Haglund, 2002; CWGC, 2009; González-Ruibal, 2007). This begs the question, therefore, why have the sites of the Holocaust not been examined to the same extent or using upto-date methods now commonplace in other areas of the discipline? Why has this period been perceived differently, with almost a 'do not disturb' attitude towards some aspects of its archaeological heritage (Moshenska, 2008: 168)? When examinations are under- taken in the future, is a unique approach, therefore, required to its investigation?

What is clear from the author's own research is that the history of the Holocaust is ongoing; these events, and examination of them, have had (and continue to have) political, social, religious, and ethical implications. Whilst historians (Roth, 2005; Kushner, 2006), artists (Lang, 2000), psychologists (Raalte et al., 2007; Kellerman, 2001), and educationalists (Short and Reid, 2004; Davies, 2000) have formulated approaches that balance these considerations, given the longevity of research in these areas, similar practices for the study of the archaeological remains of this period have not yet been established. In the past, some archaeological projects have faced criticism for failing to account for the beliefs of affected groups and this has undoubtedly impacted upon the number of subsequent projects undertaken (Weiss, 2003; Gross, 2004).

Therefore, this paper explores the untapped potential and implications of 
Holocaust archaeology and, prior to outlining the development of a methodology that had such considerations at its core, previous investigations and the variety of issues involved in archaeological examinations of this period will be addressed. Based on this, a case for the establishment of Holocaust archaeology as a sub-discipline of conflict studies will be presented.

\section{Previous investigations}

The examination of Holocaust sites is not virgin territory and, since the Second World War, a number of investigations into the nature of the war crimes perpetrated during the Holocaust have taken place. From the immediate post-war legal investiga- tions to recent site-specific surveys, the results of such projects are important to aid in the production of a robust archaeological methodology to record the remains at other Holocaust sites across Europe.

\section{Legal investigations, historical databases, and site recognition}

Early investigations of Holocaust sites were undertaken immediately after the war by specially assembled war crimes commissions, which usually comprised of medico- legal professionals tasked with the collection of evidence for the conviction of the perpetrators (IMTN, 1947; Central Commission for the Investigation of German War Crimes in Poland, 1982; Profatilov, 1945). Emphasis was placed upon verifying that the camps and graves existed rather than detailed investigation (Arad et al., 1999; IMTN, 1947). Work by Mant (1950) and the Mission de Recherché (Rosensaft, 1979 ) in the 1950s, in Serniki in the Ukraine in 1990 (Bevan, 1994), and in Jedwabne in Poland in 2002 (Gross, 2004) have perhaps been the most high profile. In the latter two cases, archaeologists were employed, although political and judicial restrictions were placed upon their work (Bevan, 1994; Gross, 2004).

A number of important surveys have been undertaken which have sought to create databases of sites. Some of these projects have been solely desk-based in nature (USHMM, 2009; Yad Vashem, 2009), whilst others have been field projects that have logged locations, brief histories, and current site conditions as part of wider surveys of Jewish heritage (Gruber and Myers, 1995; US Commission, 2005; International Jewish Cemetery Project, 2010). All of the above have focused on site recognition and identification at site-specific level with no analysis of the wider landscape context or cross-site comparisons. Only two surveys of this nature have progressed to more detailed examination of the physical remains, both of which have been undertaken by Father Patrick Desbois. Both projects are aimed at locating mass graves of this period through the collection of witness testimony, historical research, and site visits, the first in the Ukraine (Desbois, 2008) and the second in the Ukraine, Belarus, 
Poland, and Russia (Yahad In-Unum, 2011). Archaeological expertise was sought during the former project, although only a small percentage of the overall number of excavations were carried out under such supervision (Mémorial de la Shoah, 2007). Given that the second project is in its infancy, it is unclear how many sites, if any, will be examined archaeologically. Although these surveys represent the most comprehensive investigations of Holocaust sites to date, in light of the development of forensic archaeological techniques, it is unclear why archaeology has not been more integral during project designs for proposed excavations at Holocaust sites (Hunter and Cox, 2005; Hunter et al., forthcoming).

\section{Archaeological projects}

The examination of a Holocaust site using archaeological methods, for reasons unconnected to judicial proceedings, did not take place until the late 1980s. The growing number of projects that have taken place since collectively demonstrate the potential of surviving remains to reveal new insights into this period. However, an assessment of these projects indicates that their geographical distribution remains a reflection of political circumstances, societal developments and attitudes towards the sites themselves.

In Germany, the political commitment to recording sites from this period is reflected in the excavations at concentration camps Buchenwald (Hirte, 2000), Ravensbrück (Antkowiak, 2000), Dachau (David, 2001), Flossenbürg (Ibel, 2002), Bergen-Belsen (Assendorp, 2003), and Sachsenhausen (Theune, 2010); at sub-camps Rathenow (Antkowiak and Völker, 2000) and Witten-Annen (Isenberg, 1995); at the forced labour camp at Groß Schönebeck (Grothe, 2006); and at the execution site of Herberthausen (David, 2003). Many of these projects have been undertaken with a view to using the material generated in 'political education' and a number of consid- erable finds databases have been created for that purpose (Theune, 2010; 2011; Hirte, 2000). The extent of the commitment to recording Holocaust sites is reflected in a more unusual case presented by Fiedler et al. (2009), who located the former position of mass graves in Stuttgart over sixty years after the bodies had been exhumed. Using a combination of aerial photographic analysis, coring, and excavation, the investiga- tors were able to pinpoint the location of the former mass grave that had previously contained sixty-six bodies, thus allowing the local community to erect a memorial at the site (Fiedler et al., 2009). A similar, recent pledge to examine Holocaust sites using archaeological methods can be seen in Austria, where excavations have been conducted at the former Euthanasia hospital at Hartheim (Klimesch, 2002) and concentration camp Mauthausen (Theune 2010; Artner et al., 2004). 
A smaller number of projects have been undertaken in Poland, all of which have centred on the extermination camps. In the late 1980s, museum curator Pawlicka- Nowak carried out excavations at Chelmno to define the locations of barracks and crematoria, and to identify personal effects of the prisoners (Pawlicka-Nowak, 2004a; 2004b; Golden, 2003). As a result of the planned redevelopment of the memorial, excavation and coring were undertaken at Bełżec by Kola and thirty-three mass graves were located (Kola, 2000; O’Neil, 1998; O’Neil and Tregenza, 2006). This project highlighted the fact that not all of the victims' bodies were cremated as the historical accounts suggest, something which clearly has implications for the examination of other sites (Kola, 2000). However, the methods failed to account for the need to prevent disturbance to human remains, as stipulated by Jewish Halacha Law, and this resulted in the significance of the work being overshadowed by the considerable opposition presented to it (Weiss, 2003). Research at Sobibor by Kola (2001) and by a German geophysical company (Friends of Sobibor Remembrance, 2006; Yoram Hamai, pers. comm.) has been built on by the Under Sobibor project, undertaken by a team from Ben Guirion University in Israel (Under Sobibor, 2008). This investigation sought to define the nature of the structures that survive from this camp and has demonstrated inconsistencies between the historical accounts and the physical evidence uncovered (Gilead et al., 2009). Recently announced projects at Stutthof (Paris, 2011) and Auschwitz-Birkenau (Wrzosek, pers. comm.) demonstrate an emerging acknowledgement in Poland of the potential of archaeology to provide new evidence for this period. In recent years, a handful of projects have emerged elsewhere in Europe. In the last twelve months in the Netherlands, excavations have been completed at Amersfoort (Schute and Wijnen, 2010) and at the time of writing a programme of investigation has begun at Westerbork, as a result of collaborations between Kamp Westerbork museum, RAAP (Leiden), VU University Amsterdam, and a number of academic experts (including the author) (CLUE, 2011). Surveys of the sites pertaining to the Atlantic Wall are being undertaken in Norway (Jasinski, 2011) and the Channel Islands (Carr, 2009; Sturdy Colls, 2011; in prep) and remote sensing of mass graves has been undertaken in Croatia (Babic et al., 2000).

In a recent article, Theune suggested the upsurge in archaeological projects pertaining to the Holocaust stems from the fact that the offices for preservation of ancient monuments recognise the importance of these places and sites and carry out excavations when necessary, as is done at sites of older periods. (Theune, 2010: 10)

This citation highlights several important points. Firstly, there is an 
emphasis on excavation, and all of the projects to date can be seen to have centred around this. Some of the more recent projects have utilized geophysical survey, but the full poten- tial of these methods has rarely been acknowledged (Fiedler et al., 2009; Gilead et al., 2009; Theune, 2010). Indeed, Gilead et al. (2009) have suggested that sites where excavation is not permitted due to Halacha Law cannot benefit from archaeological work, thus further failing to recognize the value of non-invasive methods.

Secondly, the term 'when necessary' (Theune, ibid.) alludes to the fact that many investigations of Holocaust sites to date have been reactive responses, either to the redevelopment of memorial sites (e.g. Kola, 2000; Schute and Wijnen, 2010) or in light of impending anthropogenic threats (e.g. Guardian, 2009; International Herald Tribune, 2007). Whilst important findings have emerged from such projects, there is a need to bring studies of the Holocaust in line with other areas within the remit of archaeology and have a parallel programme of research. In particular, a Europe-wide trend that can be acknowledged is that the search for, and recovery of, mass graves of the Holocaust has rarely been undertaken by archaeologists, with the exception of a significant programme of excavations by Wright et al. (2005) in the Ukraine. Instead, the majority of investigations have been as a result of serendipitous discoveries, due to anthropogenic or natural landscape modification. Often, the bodies are removed quickly by nonspecialists, thus the significance of the context in which they were found is not considered, and rarely is anthropological analysis of the bones undertaken (Susa, 2007; International Herald Tribune, 2007). Where archaeologists have been involved, this has often been under restrictions of extreme time pressure; there is little time for desk-based research, limited recording is permitted and, in the haste of recovery, damage may be caused to the remains (Guardian, 2009). Not only does this deny the victims the dignified treatment they deserve, but valuable informa- tion about the events which resulted in their deaths is being lost. Additionally, only the discovery, rather than the actual results themselves, is usually published, and this is more often in the media as opposed to academic literature (e.g. BBC, 2007; Der Spiegel, 2006).

Thirdly, whilst Theune's assertion may be true in Germany and Austria, as shown above, there is considerable diversity in approaches to sites of the Holocaust through- out Europe and, in the majority of countries, these sites are far from treated as equals to their ancient counterparts. The lack of a legislative infrastructure to support the recording of sites from this period has also resulted in other political, social and religious issues dictating the extent of archaeological investigations. To return again to the work of Fiedler et al. (2009: 34), whilst at this site it was deemed important to 
locate empty graves and the local community 'wished to erect a monument in memory of those dark times in German history', this stands in stark contrast to other places, where even identifying unknown mass graves still containing human remains is not deemed to be necessary or desirable (Kuwałek, 2008).

Therefore, whilst the literature concerning projects in Germany and Austria represents a valuable contribution to knowledge of this period, it does not allude to the complexity of undertaking archaeological work across much of the rest of Europe. Most importantly, this, coupled with the fact that projects elsewhere have failed to address the aforementioned issues directly, has resulted in a situation whereby a consideration of the ethical implications, religious obligations, and other restraints to fieldwork have not been considered. Similarly, whilst a separate body of research exists that considers the heritage and memory of the Holocaust (Beech, 2000; 2002; Young, 1994; Lennon and Foley, 2000), the potential to combine an analysis of the physical remains and a consideration of the post-Holocaust history of sites has not been fully realized. Finally, given the number of Holocaust sites across Europe, the number of archaeological investigations can still be seen to be limited. Pilichowski (1980: 49) estimated that there were 1798 labour camps in occupied Poland alone and 5407 more in the Reich and Nazi-occupied Europe. Add these sites to the death camps, concentration camps, ghettos, massacre sites, graves, and other sites associated with the Holocaust, what is evident is the vast archaeological resource that pertains to this short period of time.

\section{Issues and considerations for archaeologists studying the Holocaust}

Whilst the Holocaust is, sadly, not the only act of genocide to have taken place in the recent past, it can be seen as a unique period in world history, given the diversity of the individuals and groups who were and, as part of its long-lasting legacy, still are affected by it. It is perhaps the number of countries involved that make it unprecedented in scale, and a diverse range of national and local factors have to be considered.

\section{Site diversity}

From a practical perspective, considerable challenges will be posed in terms of the diversity in site types, geology, climate, and the local environment across different regions and nations. Similarly, different attitudes towards heritage management and varied policies for applying for permissions will be encountered between states (Marquez Grant and Fibiger, 2010). Indeed, archaeology as a discipline will be regarded differently in different countries; for example, whilst in the UK, geophysical survey is widely used, in many European countries it is seen as a separate discipline (Gaffney and 
Gater, 2003). Considerable difficulties may be posed for foreign researchers attempting to conduct fieldwork abroad where such differences in approaches exist, and the probable language barrier, which can cause problems both during fieldwork and when applying for permission, needs to be considered from the outset.

\section{The grey area between history and memory?}

Sixty-six years have passed since the end of the Second World War. However, whilst the Holocaust may be distant in terms of time, in terms of memories and resonance in modern society, these events are current and significant. Indeed, as Harrison and Schofield (2010: 4-5) have noted, the contemporary past is "called contemporary not simply because it is "now" and recent but because it is not "closed" in interpretation nor emotional influence'. The extent to which this is the case will of course vary in nature, with respect to race, religion, cultural group, or personal experience at both individual and national level. For example, in the Ukraine, given the number of victims whose graves were never found, the Holocaust remains an ever-present com- ponent of society for many families, whilst in Israel and Palestine one of the legacies of the Holocaust is evolving daily on the world stage (Golbert, 2004; Zertal, 2010). Not only will each country have experienced the Holocaust differently, dependent upon its location, the make-up of its population, its government, and its place in the Nazi's plans to occupy Europe, but subsequent approaches to memorializing these events will differ, based on politics, social trends, religious thought, and heritage policies. Additionally, such approaches will not have remained static and since the end of the war they have evolved and diversified according to numerous factors. Consequently, the Holocaust poses a unique set of questions to both scholars and the public alike; almost everyone knows about the events and there are as many opinions concerning them. Whilst some people consider them part of their identity, others feel that this dark part of the past should not be made into a tourist attraction. Others feel little connection to events that happened outside of their lifetime; some people have a cultural affiliation, others, such as the Jewish community, may feel a religious connection; for some people these sites represent areas of reflection and commemora- tion, for others they are merely dilapidated remains of a distant past located within forests or housing developments. These opinions will also change based on modern political events, the commitment of national bodies and local councils to heritage management, and multiple other social factors.

The fact that many victims of the Holocaust and their affected family members are still alive perhaps remains the most influential factor that has 
led to the positioning of these events within the grey area between history and memory. Such a perception of this period does result in several potential issues that need to be considered by archaeologists operating in this field. On the one hand, the social relevance of these events has led to increased calls to locate the victims, maintain the memorials, and educate the public; indeed, the connections that have been made between modern genocides and the Holocaust have reinvigorated studies, ensuring this period remains in public consciousness (Beth Shalom, 2010). Additionally, people wish to commemorate the dead, visit the sites where the deceased were killed or interred, and gain a broader understanding of the lives of their ancestors through direct engagement with the past, as opposed to learning about it through secondary sources such as the media (Schofield, 2004). The continued presence of victims from this period has ensured that, for the past several decades, the Holocaust has remained 'living history' (Cargas, 1986: xiii). Kleiman and Springer-Aharoni (1995: 9) have identified two distinct strands of remembrance that have taken place: one which focused on documenting personal experiences and the other which centred on commemorating mass graves, and that 'the two operations were similar, but one looked ahead, to future generations, whilst the other looked back, to the dead'. Thus, archaeologists have to consider the wishes of these individuals and how their research can contribute to memorialization.

On the other hand, whilst "the need for filling the "black hole" between the archaeological past and the present' has been acknowledged by conflict archaeologists examining other periods, it would appear that there has been a marked reluctance, and in some cases refusal, to do so for the Holocaust (González-Ruibal, 2008: 247). The question remains, therefore, what is it about this period that places it 'off limits', as it were, to those wishing to examine its physical evidence? Has this situation arisen due the nature of the Holocaust itself, or can this be identified as a trend with regards to any other socio-historic events? Is it the fact that the events sit in this so-called grey area between history and memory that has led to this situation?

In response, comparisons can be made between the delay in investigating sites of the First World War (Saunders, 2001), the Spanish Civil War (González-Ruibal, 2007), the Turko-Cypriot war (Cassia, 2005), and those relating to Stalin's Purges (Jankauskas et al., 2005; Paperno, 2001), all of which have only been accessible to archaeologists in the last decade. All of these sites had been avoided for a number of social, political, and ethical reasons. Additionally, as with the Holocaust, sufficient time had not passed for them to be considered archaeological, according to the traditional definition of this term, but their forensic significance no longer remained. Similarly, only in recent years has the humanitarian rationale for recovering 
the victims of conflict and genocide been acknowledged, and further technologies and protocols have been developed; thus it has finally become possible to address socio-historic sites in the same way as recent ones (Hunter et al., forthcoming). That said, the Holocaust has still been left behind in archaeological terms, despite the fact that significantly more sites across a wider geographical area pertaining to this event exist than for many others of the twentieth century. Indeed, if time was the major contributing factor, then surely other sites relating to the Second World War would also not have been examined, yet there has been a keen interest in the fortifications, aircraft, camps, and other structures relating to the war itself (Gaffney et al., 2004; Williams and Williams, 2007; English Heritage, 2003).

By way of explanation concerning recent conflict in general, GonzálezRuibal (2008: 248) has suggested that 'it seems that, for both scientific and personal reasons, we cannot study what we or our relatives have directly or indirectly experienced'. This raises several further important questions. Why have well-established protocols been developed, allowing the immediate response by international teams to recent disasters and genocides, yet not been employed at Holocaust sites? Similarly, why have countless other periods of our recent past been subject to detailed archaeological and historical enquiry? Indeed, why has the Holocaust been studied intensively from a historical perspective if we are unable to address events in living memory? It would appear that, for whatever reason, from an archaeological perspective, the Holocaust, despite its similarities with other conflicts from this period, is sometimes deemed 'too near and too painful' (Polonsky and Michlic, 2004: 43).

\section{Politics - official histories}

Since the war, various groups have attempted to shape the perceptions of the Holocaust and Nazi Occupation of Europe and, in many cases, national 'official histories' have emerged, often with an underlying political agenda directed towards limiting discussion on more contentious aspects of the past (Polonsky and Michlic, 2004; Cruikshank, 1975). In historical dialogue, certain common ideas have been presented, such as the fact that the majority of the Nazis' victims were cremated and all physical traces of some of the camps were entirely destroyed (IMTN, 1947; Chrostowski, 2004; Sweibocka, 1995). Public impressions of the Holocaust can be seen to have derived from common representations presented in the national and international media: the piles of emaciated bodies photographed by the liberators, the gas chambers, the railway lines to the camps (Hayes, 2003). 
Such a prescribed approach to general public education has also been taken with regards to the presentation of the physical remains. 'Conscious political decisions' to preserve Auschwitz-Birkenau and present it as a symbol of the Holocaust have been maintained since the end of the war (Sweibocka, 1995; Figure 1). Whilst this approach may be due to the sheer scale of sites throughout Europe, and the need to have a centralized education strategy, it has attracted criticism for entering the realms of so-called 'dark tourism' and 'infotainment' (Lennon and Foley, 2000). Various critiques of the presentation of these sites have been presented in the literature, from those that accuse archaeologists seeking to bolster tourism of being 'victims of fast capitalism' (Matthews, 2009: 87), to those that claim that 'the new museum and memorial culture of recent years betrays any real sense of history and has instead turned to spectacle and entertainment' (Huyssen, 1994: 12). If increased efforts are to be made to examine the physical remains, particularly in the context of their potential contributions to heritage and education, then these issues clearly need to be addressed. Additionally, such an approach has been at the expense of other sites, some of which have become neglected and misrepresented, in particular the smaller massacre and cemetery sites. By channelling the history of the Holocaust through a selection of well-known sites, this has served to create an image of the Holocaust that centres around the systematic and industrialized processing of victims, as well as one which implies that the only remains that survive are visible above the ground: the Nazis purportedly destroyed all other traces of the camps, ergo, there is little need for archaeological investigations. 


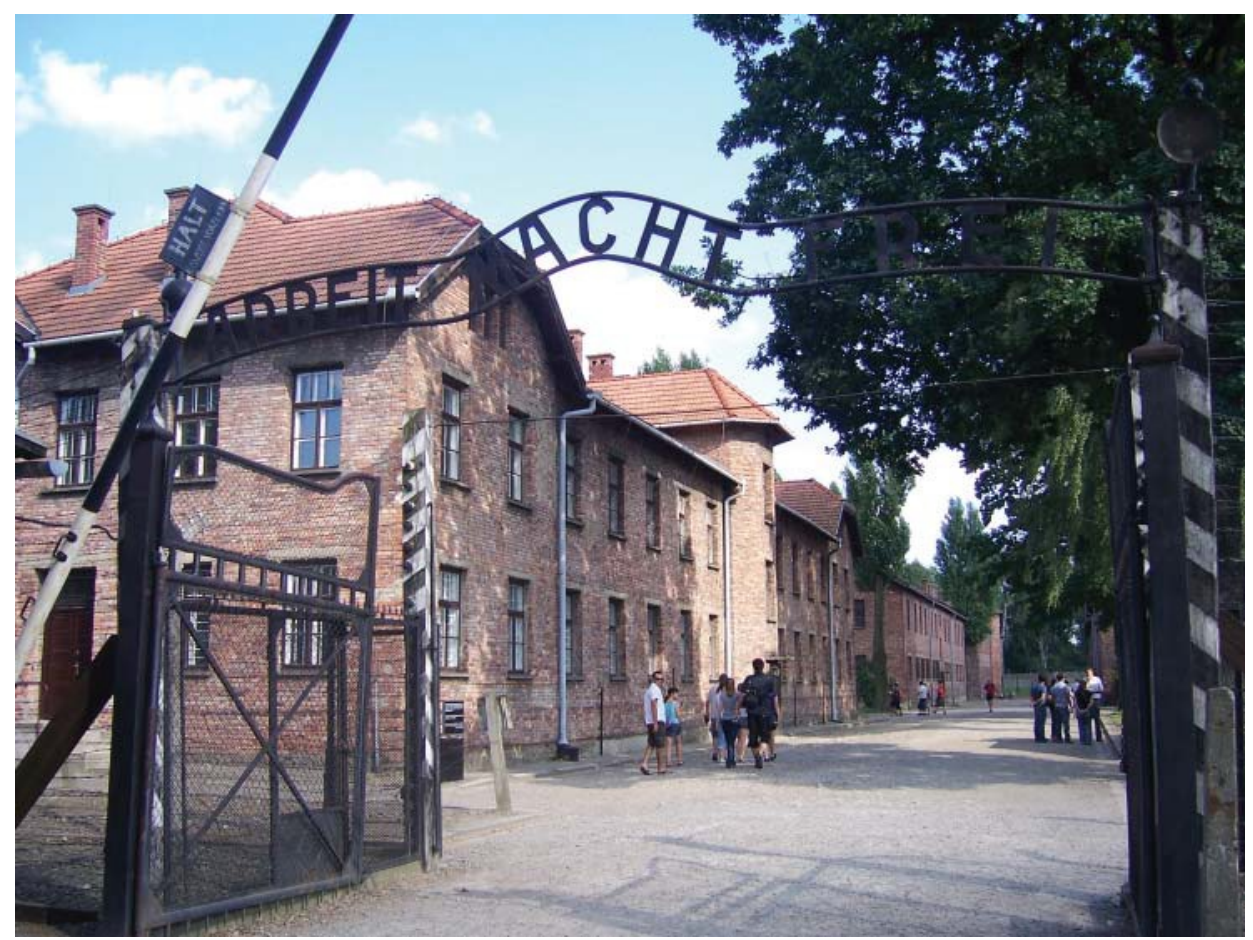

Figure 1 The gates of Auschwitz, which have become one of the iconic images of the Holocaust (author's own photograph).

In some countries and amongst some groups, there is an apparent desire to separate the killings that occurred from the events of the Holocaust entirely, as reflected in the semantics used and the exclusion of the killings of the Jews from discussions. Instead, there has been a focus on the deaths of civilians, whilst memorialization has been 'influenced by and become a focus for the politics of nationalism' (Pollard, 2007: 143). In Poland, for example, attempts to seek victims not of Catholic affiliation have been deemed 'antiPolish' by past governments (Polonsky and Michlic, 2004: 9). Terms such as 'martyr' have been used to describe Polish victims, with the media and national curriculum focusing almost exclusively on the massacre of Polish soldiers at Katyń (Ministry of Foreign Affairs, 2008). Elsewhere, there are attempts to stress that only work camps and not concentration or extermination camps existed in a given location, thus attempting to separate the deaths caused through ill treatment from direct annihilation. For example, in France there appears to be a marked reluctance to address the impact of the Holocaust, which, according to Aulich (2007) stems from fears over admitting the crimes which were carried out. Therefore, these approaches place the atrocities 'at the margins of memory' and allow disassociation of cultures from the darker parts of history (Aulich, 2007: 195-96). Not only does this defile the memory of those who died in these camps, but it ignores the diversity of the Holocaust. Consequently, the case studies described later in this paper were selected in part to demonstrate the diversity of the Nazi Occupation as presented through the physical remains. 
In many cases, current approaches to the physical remains of the Holocaust are consistent with Bernbeck and Pollack's (2007) assertion that 'the perpetrators and their actions are missing in modern heritage, which prioritizes the achievements of the victims'. Often there has been a focus on defining the numbers of victims or simply the fact that the victims were present in a given area (cited in Matthews, 2009: 88; Kola, 2000). Attention has been placed on themes such as 'passive suffering' and 'vicarious victimhood' (Novick, 1999: 5), something which is reflected in the presentation of tourist sites at which visitors are interpolated into passive subject positions and encouraged to accept a dominant narrative in which they sympathise with innocent victims, identify with brave national heroes, and demonize, vilify and dehumanise the enemy. (Lisle, 2007: 98).

An almost mythical veil has been drawn over some Holocaust sites, consistent with approaches to other sites of the contemporary past; "these names seem to conjure images of a devastated landscape, hideous industrialized war, and infinite pity for those who fought' (Wilson, 2007: 227). Perhaps it is this opinion that has also contributed in part to the view that Holocaust sites should remain untouched, preserved in time as sacred landscapes (Jacobs, 2004). Little attention has been paid to how landscape studies can reveal information about the Nazis' methods and plans for extermination, their methods of camouflage or the intentions of groups of perpetrators. This is where taking a more forensic archaeological approach can help to rectify this, thus ensuring that both the victim and perpetrator archaeology can be emphasized; the grave sites can be located and commemorated, whilst the development and intention of the Nazis' plans can be demonstrated.

This apparent dehumanization provides an escape from acknowledging the uncomfortable reality of humanity; that is, that it is capable of war, aggression, and persecution (Moshenska, 2008). As Gould and Schiffer (1981: 65) have argued, 'more than anything else, these modern material culture studies show us that we are not always what we seem, even to ourselves'. It is easier to face these uncomfortable aspects of the past believing that the Nazi aggressors were somehow different, separated from the rest of society, overcome by inhuman rage, than it is to admit that it is precisely because the perpetrators were human that these events are so terrifying. Certain subjects are also seemingly off limits or at least frowned upon, such as the involvement of children and women in perpetrating crimes (Sofaer Derevenski, 2000; Gilchrist, 2003), and instead of embracing studies that have sought to examine issues such as collaboration and the role of 'ordinary men' as revolutionary, many in the past have sought to marginalize this research (Browning, 1993; Bunting, 1995). Additionally, 
attempts have also been made to describe the Holocaust as a religious struggle where the Jews were chosen by God to suffer for mankind but, as Garber has argued, in order to fully understand the events it should instead be seen as one more tragic example of man's inhumanity to man, in which both murderers and victims are ordinary human beings in an extraordinary situation, a secular event without either saints or demons. (Garber, 1994: 4).

Seemingly, we need to find a way to address such issues and recontextualize the events. The fact that the physical evidence of the Holocaust is capable of providing a vivid reminder of the crimes perpetrated by these individuals is perhaps both the biggest strength in this regard, but also its biggest challenge, given that archaeological approaches forces uncomfortable aspects of the past to the forefront of memory (González-Ruibal, 2008).

There is a need to move away from the notion that the presence of historical sources precludes the need for the collection of physical evidence, given the humani- tarian, scientific, academic and commemorative contribution that the latter can make. However, this is likely to be easier said than done, as permission for work is unlikely to be granted where the value of archaeological approaches is not fully understood. Additionally, researchers studying this period need to consider how we will address and account for the fact that our research may dispute the aforemen- tioned 'popular histories' (Baker, 1988; McGuire, 2008).

It would also appear that archaeologists, perhaps wary of these issues, have to date reacted in a similar way to historians thirty years ago; as Browning notes, often their response was to treat the Holocaust as an aberration - a freakish inexplicable event - not to be analyzed in the same way historians approach other occurrences and not to be assimilated into our selfunderstanding. (Browning, 1993: xi)

Separating the events as somehow inhuman serves to disconnect them from the traditional well-tested mechanisms for investigating archaeological sites and by seem-ingly accepting that these events were somehow different, we as a discipline are able to bury our head in the sand.

\section{Politics - national and societal divisions}

Despite the time that has passed since the Holocaust, in many countries it still repre- sents a contentious and commanding issue. At the most serious level, the examination of the physical remains of the Holocaust has incited further conflict, for example in the former Yugoslavia, where the exhumation and memorialization of Holocaust victims led to war and genocide in the 1990s (Skinner et al., 2002). Considering lessons learnt in the search for victims from other genocides, as Skinner et al. (2002:297) 
have argued, such investigations can facilitate propaganda, thus 'archaeologists have to be careful not to inspire [. . . ] genocide by providing a pedigree for hatred with simplistic consumer-orientated interpretation of a complex past' (Pyburn, 2009: 162).

Such an approach reflects another trend in respect to the Holocaust; that is that, irrespective of the details of what really happened, in many cases 'the past has [. . .] been reshaped by an altered present' (Pullan, 2007: 89). Thus, modern political relationships have often shaped approaches to representations of these events and its material past. For example, the former example of a focus on Katyń is also reflective of a current heightened hostility towards Russia that is felt in Poland (BBC, 2011; Meng, 2010). Other examples demonstrate this trend and how approaches to these sites have altered and diversified in the decades since the war, reflecting the social and political changes that have occurred. One particularly good example of this is the various attitudes that have evolved in Germany. Whilst an uncomfortable silence was maintained about the Nazi atrocities for many years, the decision to examine the site of the SS, SA, and Gestapo headquarters represented a dramatic act of defiance and remembrance, which incited the West German government to relent and support the venture (Baker, 1988). However, the fact that East German artists were imprisoned for entering the competition to design a new memorial at this site demonstrates how modern political thought influenced its representation (Moeller, 2006; Baker, 1988). Following the collapse of the Berlin Wall, attitudes changed again and the subsequent developments in Germany have now resulted in an ethos with regards to the Holocaust that 'draw lessons from the past with a view to building a better future' and acknowledges the responsibility of individuals and institutions (Knischewski and Spittler, 2007: 166).

Similarly, in the former Eastern Bloc countries, it was not permitted to discuss the atrocities of the Second World War under Communist rule but, since the 1990s, and in recent years in particular, changes in approaches have emerged (Paperno, 2001; Jankauskas, 2005). Although many attempts to address these events have been made at local level, usually inspired by academics or specific projects, as with the searches for mass graves in Russia and the Ukraine, some national and even international groups have emerged with government backing (Paperno, 2001; Desbois, 2008; Wright et al., 2005). For example, the Commission of Historians in Latvia (2001), the Commission on Concealed Mass Graves in Slovenia (Ferenc, 2008), the Estonian International Commission for Investigation of Crimes Against Humanity (2006), and the Institute of National Remembrance in Poland (2009) are all active. However, the remit of these groups varies 
considerably and the majority are limited to historical research. Particularly concerning those groups that were not established until rela- tively recently, it is probable that it will be a long time before suggestions are made to routinely examine the physical remains relating to these events. The long period of time in which it was not deemed acceptable to even discuss the events of the Holocaust offers one explanation as to why the physical remains of this period have undergone limited investigation. Such issues may be far beyond the control of researchers, but it is vital that a consideration of them forms a fundamental part in the development of search strategies.

Given the fact that archaeology has often been perceived as both physically and metaphorically digging up painful aspects of the past, the act of conducting archaeo- logical research can in itself be seen as political (McGuire, 2008). Whilst it is clearly important to ensure that research does not become sanitized and a process of 'stamp collecting' (Saunders, 1998:9), the political resonance of the excavations at Serniki and Jedwabne, for example, have demonstrated the issues that can arise when con- ducting invasive investigations at Holocaust sites (Wright et al., 2005; Gross, 2004). Indeed, those investigations undertaken, particularly by non-natives, 'just to satisfy a desire for knowledge about the past' (Wright et al., 2005: 137) will not always be well received and 'memorial and educational processes need to pay considerable attention to containing the threat of both socio-political and emotional fragmentation' (Field, 2007: 228). Questions need to be asked over whether the potential damage, upset, and upheaval caused by such investigations is justified in light of its potential to enhance public knowledge and understanding of the past; thus there is a need to thoroughly consider the significance and impact of the research, both in scientific and societal terms (Pyburn, 2009).

\section{A hierarchy of atrocity?}

Whilst in some countries conscious efforts have been made to shape perceptions of the Holocaust, the lack of study with regards to the physical remains in other countries may stem from the fact that other events have been deemed, over time, to have more social relevance on a daily basis. Indeed, what can almost be described as a hierarchy of atrocity has developed in some European countries. For example, it is apparent on memorials and in heritage displays in countries such as Estonia, Latvia, and Lithuania that emphasis is often placed upon the crimes perpetrated against these nations by Russia, both during the Second World War and in subsequent years (Estonian International Commission for Investigation of Crimes Against Humanity, 2006). It is likely due to the fact that the impact of these Russian regimes is still felt by the citizens in these countries, and still has a dominant part to play in political thought, whilst the Nazi 
regime's remit was limited to the war years (International Commission of Historians in Latvia, 2001). Additionally, the fact that the Germans were often viewed as the lesser of two evils, as it were, in many Eastern European countries by those not persecuted during the Holocaust, has also led to a marked difference with regards to the investigation of Nazi crimes. Perhaps for many who have lived through the 'Total War' period of 1914 to 1989, the Holocaust, for whatever reason, fails to stand out in several decades of violence and bloodshed (Schofield, 2004: 1). Alternatively, Lowenthal (1998: 77) cites another view based on the responses of Israeli, Arab, and Jewish children: 'that Jews mourned grandparents lost in the Holocaust amazed Arab children: "You are missing your families from 50 years ago, while my relatives are being killed today"”.

Similarly, during the course of research undertaken by the author, it was often remarked that considerably more people fell victim to the Stalinist regime, that the deaths of those who died under the dictatorial oppression in Japan have never been investigated, that the investigation of sites of Katyn was long overdue, and that the majority of the graves relating to the Spanish Civil War, Turko-Cypriot War, or other conflicts during the twentieth century remained unlocated. It was questioned, why did this project not focus on these events instead?

Such reactions highlight several issues with the approach to studies of the material remains of the Holocaust. First of all, it demonstrates that people generally believe that the Holocaust has been studied intensively by historians and question what further information such studies can contribute, thus demonstrating the emphasis placed upon historical enquiry relating to this period and a widespread failure to acknowledge the added value of archaeological investigations. Secondly, it reveals how some believe there has been a saturation of studies relating to the Holocaust in the general field of investigations of twentieth-century conflict (Krondorfer, 2008). Indeed, at a recent colloquium considering remembrance activities with regards to the civilian war dead of the Second World War, a discussion of the victims of the Holocaust was notably absent, the organizers feeling that to include this would be to dwarf the significance of these smaller scale. Additionally, these approaches further demon- strate the existence of this socalled hierarchy of genocide, in which people place certain values, based, for example, upon numbers of victims or the length of the regime or war in question, upon the need to investigate sites. Perhaps most signifi- cantly, it raises further questions over why it is deemed acceptable to investigate the physical remnants of these conflicts, yet fervent opposition to doing so with regards to the Holocaust has been encountered. One possible answer lies in the fact that, as previously noted, in some cases the Holocaust is not seen as 
unique, and this is why the study of its physical remains has not been given precedent over other periods.

\section{Society and cultural identity}

Building on this idea, it would appear that, both in the past and in contemporary society, the feeling that the Holocaust does not, or should not, play a significant part in the cultural identity of communities and individuals has impacted upon the treatment of sites. With reference to this period, such beliefs are twofold.

Firstly, in the immediate aftermath of the Holocaust, it would appear that the desire of the affected population to move on was prevalent, a trend which has also been commonly noted in respect to other conflict and mass disaster sites (Perera and Briggs, 2008; Tsokos et al., 2006). Communities took responsibility for burying the dead hastily, often in mass graves and without any form of identification (Abzug, 1985). Several explanations for this can be cited. Firstly, it was often for practical reasons, such as the prevention of disease and the advancement of decomposition, that there was an immediate need to dispose of the corpses (Abzug, 1985). Secondly, it was deemed necessary to ensure that the bodies were given a formal burial and that any remaining chances to uphold religious obligations were acted on (Rzeźniak, 2007). Perhaps most notably, there was a desire to turn attention towards the rebuild- ing of communities that had been savaged by war and violence; as Baker has argued, 'survival came before remembrance' (Baker, 1988: 95).

For some communities, the physical removal of bodies also appears to have repre- sented a psychological act of burying the past, something which was coupled with the widespread removal of structures and other visible signs of these events (Beder, 2002). Although many memorials were subsequently erected, there has been an evident trend since the end of the war that indicates that many communities do not wish to dwell on the past (Meng, 2010). For some communities, understandably they do not want to be known predominantly for terror and bloodshed, for others this has been to fears over claims of collaboration with the Nazis (Bunting, 1995; Carr, 2009; Jacobs, 2004).

Also, in modern society in particular, people often feel little or no connection to the events or the individuals persecuted. Where individuals live in an area where atrocities occurred, they may feel considerable resentment for the minority groups who may no longer live in the area in question but who may attempt to memorialize the events, a problem that has been noted at many conflict sites from different periods of history (Pullan, 
2007). As Cohen (2001: 234) has argued, 'all over the world, commemorations of atrocities have turned into memory wars, the forces of denial and acknowledgement literally battling it out for territory'. Thus, in general terms, these issues are not unique to the Holocaust and lessons can be learnt from the work of other researchers dealing with these contentious fields of enquiry.

For example, Paperno (2001: 107) cites the comments of Maryna Shleimovych, a local resident interviewed in the course of archaeological investigations into the Soviet atrocities during the Second World War, who stated, 'here you are again with your graves! History has stuffed the whole earth with corpses! What do we have to do with this? Yes, I know that they shot people here once upon a time, but this was a long time ago, and I like strolling here'.

This trend can be seen for other conflicts. Papadakis (in Lisle, 2007: 99) has noted in Cyprus that the preoccupation with the events of the Turko-Cypriot war has made it impossible for certain communities to move on and has caused them to become 'so entrenched in their opposing ideological positions that they can only hear "echoes from the dead zone" reflecting and reinforcing their own prejudices'. Polonsky and Michlic (2004: 2) have argued, 'the traumatic past, whether private or national, exists. . like a foreign body of which we cannot rid ourselves'. Therefore, the conflict- ing opinions over the treatment of these sites represent an ever-present, even if unspoken, component of society, and it seems probable that these opinions will emerge to the surface and be impassionedly vocalized when further work at Holocaust sites is proposed (Harrison and Schofield, 2010).

Therefore, the issue of so-called ownership of the past needs to be carefully considered and again comparable examples are well-attested to in the literature pertaining to conflict archaeology. To whom does the past belong? Does direct involvement with the event in question provide guaranteed ownership, or does living in an area affected by conflict automatically result in the assimilation of these events into an individual's cultural heritage? Who has the right to make decisions on the future of heritage sites? Questions such as these are constantly debated in both the public and academic arena (Carman, 2005; Purbrick et al., 2007; Smith and Akagawa, 2008). Given the aforementioned number of groups and generations affected by the Holocaust, such ownership issues are exacerbated, the majority of which will have a local or national remit. It would appear that the current condition of sites, and the widespread lack of knowledge that exists concerning the physical evidence of the Holocaust, is a reflection of the struggle between these various groups who have 
attempted to shape the history and memory of these events to date.

\section{Religion and ethics}

As well as national issues and diversity, the various different religious and minority groups affected by the Holocaust also presents a unique set of considerations for researchers. Jews (practising or by relation), Christians, atheists, Sinti, Roma, the disabled, the sick, homosexuals, and perceived political enemies were all persecuted, irrespective of age, social status, or gender. Both between, and even within these groups, considerable diversity existed in terms of perceptions of death and burial in particular, and similarly diverse views are held by subsequent generations with a connection to these events. Several additional groups exist, whose needs must be consid- ered with respect to the establishment of memorial sites, ranging from survivors, those that witnessed the violence who either tried to protect those being persecuted or failed to oppose it, victims of propaganda and families of those who died and survived, through to students, educators, historians, and tourists (Field, 2007). Simi- larly, the beliefs, opinions, and needs of all of these groups need to be considered when examining and presenting the archaeological remains of this period in order to avoid these sites becoming what Pollard (2007) has alluded to with respect to battlefield sites, that is twofold contested spaces, upon which battles were fought and then conflict arose whilst attempting to make decisions over how to memorialize them.

\section{Mass graves, cemeteries and cremations}

In particular, issues arise in relation to the vast amount of mass graves, cemeteries, and cremation pits that pertain to the Holocaust, the majority of which remain unmarked. As already noted, the rationale for locating the remains of the victims of other genocides have been well attested to in the literature, inciting the development of new branches of forensic archaeology and anthropology, the creation of standards and guidelines, and a deep-rooted understanding of the personal benefits in terms of mourning a definitive loss (Schmitt, 2002; Williams and Crews, 2003; Hunter and Simpson, 2007). With regards to the victims of the wars of the twentieth century, international thought has centred on the need for 'finding the fallen' (Moshenska, 2008: 167), whilst there has been renewed interest in the form of projects such as that at Fromelles aimed at locating mass graves (CWGC, 2009). Similarly, in general archaeological terms there has been widespread interest in finding skeletal remains, with Williams and Williams (2007: 52) noting one of the most common questions at excavation sites being 'have you found any bodies?'. The ability of the human remains of our ancestors to foster a sense of identity and increase our understanding of previous cultures is also evident, with the physical 
existence of a body seemingly encouraging greater empathy with people from the past (Williams and Williams, 2007). However, the majority of these instances have dealt with Christian victims and it has generally been accepted that bodies that have been clandestinely buried should be reburied individually (ICMP, 2011; BABAO, 2008).

Such sentiments have rarely been expressed in relation to the Holocaust. Instead, searches for the bodies of the victims have been largely limited to acknowledging that graves exist as opposed to their detailed investigation (Kola, 2000; US Commission, 2005). There have been no systematic attempts to create a central record of sites or to develop standards for the examination of remains when they are located, some- thing which has often resulted in their inappropriate treatment when they have been found serendipitously (Guardian, 2009). Additionally, in some places, there has even been a notable attempt to avoid acknowledging their very existence, a fact that may stem from a belief that to acknowledge them would be to resurrect painful issues (Schmitt, 2002). Similarly, as has been noted by many archaeologists studying indigenous populations, the examination of human remains can expose social, political, and religious tensions more readily than other types of evidence (McDavid, 2002).

\section{Approaches to death and burial}

Several important questions arise with regards to the beliefs of the different groups affected by the Holocaust, in particular the treatment of the dead and memorialization. For example, if a grave is located serendipitously, do we adhere to modern opinions on burials or those held by people in the past? Should the current local inhabitants be allowed to select commemoration methods or does historical precedent dictate that this should fall on the ethnic or religious group to whom the victims are located? Should national or religious opinion take priority (Payne, 2009; Lilley et al., 1994)?

Perhaps most pertinent are questions surrounding the religious affiliations of the victims. Should graves believed to contain the bodies of individuals from different religious backgrounds be memorialized according to the traditions of all religions represented or the one to which the majority of victims are thought to belong? Issues with this have already been noted at existing Holocaust sites. For example, the erection of crosses at Auschwitz sparked outrage among the Jewish community (Smith, 2007; Zubrzycki, 2006). Similarly, whilst the national heritage bodies in Poland stipulate that the hair from the victims of the Holocaust can be displayed in museums, the Jewish community believe it should be buried according to Halachic traditions (Auschwitz-Birkenau Memorial and Museum, 2010; Lisle, 2007). Even within the same religious group, different branches will have differing opinions. Similarly, is it ethical 
that we assume that all victims considered to be Jewish were actually practising Jews and that they would have wanted to be buried or memorialized according to these traditions? For example, a number of Jews reportedly converted to Christian- ity; how should they be commemorated (Garber, 1994; Levy, 1992)? Additionally, whilst the Jewish community have a memorial tradition that encourages remembrance, gypsies have 'contributed to [. . .] forgetting, because they have chosen not to differentiate within nor dwell on their long history of persecution' (Clendinnen, 1999: 8; Fonseca, 1995). Is emphasizing the persecution of these individuals against the will of their descendants ethical?

Of course, considerable difficulty surrounds answering these questions, given that modern opinions regarding ethics, religion, and commemoration will impact upon decisions made. Additionally, the information regarding an individual's circumstances will rarely be available and, if it is, the sheer number of victims would make it impossible to make such decisions on an individual basis. Indeed, this is exacerbated further where no excavation and identification of the remains is carried out; one must assume, albeit based on historical evidence, who may be buried in the grave in question and, therefore, what methods of commemoration are most appropriate.

As Moshenska (2008: 161) has stated, 'issues such as respect for the dead are arguably of greater ethical significance in the communication of research findings than the research itself'. Arguably, with regards to the Holocaust, without a thorough under- standing of the need for the respectful and appropriate treatment of the dead in terms of religious and ethical principles, such research findings could not even be derived. Without having unequivocally demonstrated that these issues have been considered during the development of a methodology, there is a risk that researchers will not be granted permission to examine Holocaust sites. Perhaps limited attempts to examine the sites have resulted from the ethical and moral dilemmas posed as a result of the diversity of nations, groups, and individuals affected.

\section{Jewish Halacha Law and archaeology}

These approaches to Holocaust sites have, in part, stemmed from the fact that the majority of victims interred in these graves were Jewish. Consequently, a consideration of Jewish beliefs with regards to death, burial, and memorialization, and the approaches that have been taken by other groups and nations to remembering these victims, should be central to all studies of heritage and archaeology of this period. To date, there have been few attempts to do this and the majority of Jewish sites across Europe are neglected and vandalized (Gruber and Myers, 1995; Cesarani, 2005). 
This often reflects current attitudes towards this group in many areas. Given that only limited numbers of Jews have remained in countries such as Poland since the end of the war, they have little direct control over the management of their cultural heritage (Gruber and Myers, 1995; Jacobs, 2004).

Jewish religious law, or Halacha, provides guidance for practising Jews and makes several observations concerning death, the treatment of human remains and commemoration (Rosenbaum, 1976). The methods of extermination and disposal of victims by the Nazis, and the 'indignity of mass death', denied the international Jewish community the ability to bury and commemorate the dead according to these traditional principles (Smith, 2007: 59). In particular, the cremation of the bodies of the Jews represented the highest level of profanity towards the deceased given that the Torah and Talmud proclaim it a disgrace to burn a body and a restriction upon the resurrection of the individual (Melmed LeHoil, Yoreh Deah 114:2 (Rabbi Dovid Tzvi Hoffman, Germany, 1843-1921); Achiezer (Rabbi Chaim Ozer Grodzinsky, Dayan of Vilna, 1863-1940). However, Halacha Law also stipulates that the disturbance of human remains (for whatever purpose) is forbidden, thus restricting the actions of archaeologists in terms of the ability to excavate Holocaust sites where inhumations are suspected (Rosensaft, 1979). As Rabbi Moses Feinstein (in Rosensaft, 1979: 164) argued, 'the dead rest in their place of burial. Not only is it forbidden to exhume the bodies but even to open the graves is strictly prohibited'. The comments of the Chief Rabbi of the Jewsbury excavations in York highlight the position of the Jewry with regards to the scientific investigation of human remains: whatever the scientific and historical loss, I hope that you and the general public will appreciate our paramount concern for the reverence due to the mortal remains which once bore the incomparable hallmark of the Divine image and which, we believe, have an inalienable right to rest undisturbed. We are convinced that the dignity shown to humans even centuries after their death can contribute more than any scientific enquiry to the advancement of human civilisation and the enhancement of the respect in which humans hold each other. (Rahtz, 1995: 197).

This statement highlights several important issues. Firstly, it demonstrates that, even though the remains have not been afforded the dignity of burial according to Jewish burial law, they will not be exhumed to facilitate this; thus the belief that the dead should rest where they lie overrides the need for traditional burial rites. Similarly, the Rabbinical authorities proclaim that a lack of intrusive investigation at these sites will actually facilitate greater peace and understanding than if such work was allowed to go ahead and the 
bodies were removed for reburial (Rahtz, 1995). Whilst it is not the place of the archaeologist to question this ideology, clearly this raises important considerations regarding the role of archaeological research, particularly as the commemorative and humanitarian rationale usually associated with its application in conflict or atrocity situations have been muted by religious objection.

Therefore, this dictates that archaeological investigations involving burials must revolve around a methodology which accounts for Halacha Law; thus being non- invasive in their approach, ethical and respectful in their undertaking, and valid in their commemorative and heritage function. Indeed, archaeology can make a consid- erable contribution to Jewish studies with respect both to the Holocaust and other sites at which human remains are located, in that various methods are available that preclude the need for ground disturbance (described below). The additional informa- tion generated about the sites in question can contribute to the memorialization of the victims and foster the Jewish tradition of remembering the past (Young, 1994). Whilst at known sites, specific information about the exact locations of graves, cremation pits, and other features connected with the deaths of the victims can be derived and will contribute to the process of 'sacred memorialization' already in place, the location of previously unidentified sites can ensure that Halachic traditions based on the need for the dead to have a known and marked grave can be upheld (Jacobs, 2004: 311).

\section{Holocaust Landscapes Project}

The Holocaust Landscapes Project was established in order to facilitate the development of a methodology that demonstrated the benefits of archaeological work at Holocaust sites, whilst compensating for, and accommodating, the variety of issues specific to studies of this period. This project originally formed part of the author's doctoral studies and continues as a collaborative research programme with partners throughout Europe.

In recent years, forensic archaeologists in particular have advocated the use of an interdisciplinary approach to site evaluation on the basis that 'there is no single perfect method' that will reveal the extent and nature of a site (Hunter and Cox, 2005: 27; France et al., 1997). Additionally, given the religious and ethical concerns over excavations, a multidisciplinary noninvasive approach utilizing Digital kinematic GPS and Total Station Survey, Ground Penetrating Radar (GPR), resistance survey and electrical imaging alongside aerial photographs, cartographic sources, and historical evidence was devised. Similarly, a number of techniques utilized in forensic archaeological searches were also employed; a consideration of 
taphonomic indicators (such as vegetation change and microtopographic landscape modification caused by ground disturbance), analysis of decomposition/preservation and body deposition practices, offender profiling, and an assessment of landscape change, and the Nazis' attempts to hide their crimes.

The intention of this project is not to suggest that non-intrusive methods should replace excavation or that these methods will be applicable to all sites pertaining to the Holocaust. However, by demonstrating the benefits of a multidisciplinary approach and the individual merits of each of the techniques used, it the intention to suggest that, in cases where excavation is not permitted, there are alternative means to gaining substantial information about buried remains. The assimilation of archaeological data and historical information is aimed towards facilitating advanced interpretation and their use in heritage and education strategies is advocated; thus providing a more potent and tangible reminder of these events for future generations.

Similarly, as observed above, the history of the Holocaust did not end with the abandonment of sites by the Nazis or with the fall of the Third Reich. Its legacy has been far-reaching and has not remained static, having diversified according to political and social change differentially throughout Europe. An examination of these changes is deemed crucial in order to understand the extent and nature of the landscapes examined. From a practical point of view, this facilitates greater understanding of the landscape change that has taken place since the war, thus allowing features to be more readily characterized. Additionally, in many cases, the condition of a site is often a physical manifestation of the societal tensions and divisions which may relate to perceptions of the Holocaust and the groups involved, or problems that have evolved in the years following the war. Indeed, a theoretical approach to landscape archaeology is proposed, whereby the landscapes are viewed as 'interactive platforms for human experience' in order to consider broader issues such as ownership, cultural heritage and, in turn, the ethical responsibilities of researchers (Chapman, 2003: 20).

\section{Case studies}

Two case studies will be discussed here to demonstrate how the aforementioned issues impacted upon fieldwork and the benefits of the methodology selected. It is not the intention to discuss at length the individual features recorded, as these will be presented elsewhere (Sturdy Colls, in prep; 2011), but to provide an overview of the results gained in order to demonstrate their implications for studies of this period. 


\section{Treblinka, Poland}

The decision taken at the Wannsee Conference to carry out the Final Solution, com- monly defined as the plan to annihilate Jews across Europe, facilitated the need for mass extermination centres, which would be under the control of Operation Reinhard staff (Baxter, 2010). Treblinka, located $100 \mathrm{~km}$ from Warsaw (Figure 2), would be designated such a site and, comprising of a complex of gas chambers, barracks, mass graves, and, later, cremation pyres, it would become the massacre site of over 800,000 European Jews, Poles, and gypsies during the Holocaust (Wiernik, 1944; Arad, 1987).

However, despite Treblinka's significance in the implementation of the Final Solution and the history of the Holocaust as a whole, knowledge of the site's former function has faded from general public consciousness and, excepting a ten-day survey in 1945 (Łukaszkiewicz, 1946) and a GPR survey undertaken by a Holocaust revisionist (Irving, 2000), there have been no attempts consider the potential archaeological remains pertaining to it. Indeed, survivor Richard Glazar (1999: vii) has high- lighted a well-known reference work that cited an incorrect location for Treblinka, indicating 'how much we have forgotten about the history of this camp', something which is echoed by the number of people who, when questioned, are unsure where the site is situated. Additionally, the lack of mapping and information at the site itself is indicative of how little is understood about its extent and layout, whilst the symbolic memorial addresses only the camp boundary, the railway line, and the purported locations of the mass graves and cremation pits; thus the locations of further graves and any of the camp structures have yet to be identified (Figure 3).

\section{Figure 2 Location plan of Treblinka}

It would appear that this situation has arisen as a result of numerous factors, some of which relate to the condition of the site itself and others which stem from the perceptions of it. Unlike camps such as Auschwitz and Majdanek, the extermination camp at Treblinka was deconstructed by the Nazis and no original standing remains are visible at the site. The site is also located in an extremely remote area and the majority of victims killed there were Jewish, the relatives of whom mostly no longer live in the locality or even in the country (Jacobs, 2004). Political circumstances in Poland have also impacted upon approaches to the site, which was not designated a memorial until the early 1960s (Radecka, 2011). Given the brutality and scale of the killings at Treblinka, few witnesses also survived to provide testimony to the events that occurred there (Chrostowski, 2004; Arad, 1987). As such, accounts have histori- cally relied on the limited amount of documentary 
evidence available which has resulted in the popular perceptions that Treblinka was entirely destroyed and that all of the victims' bodies were cremated without trace.

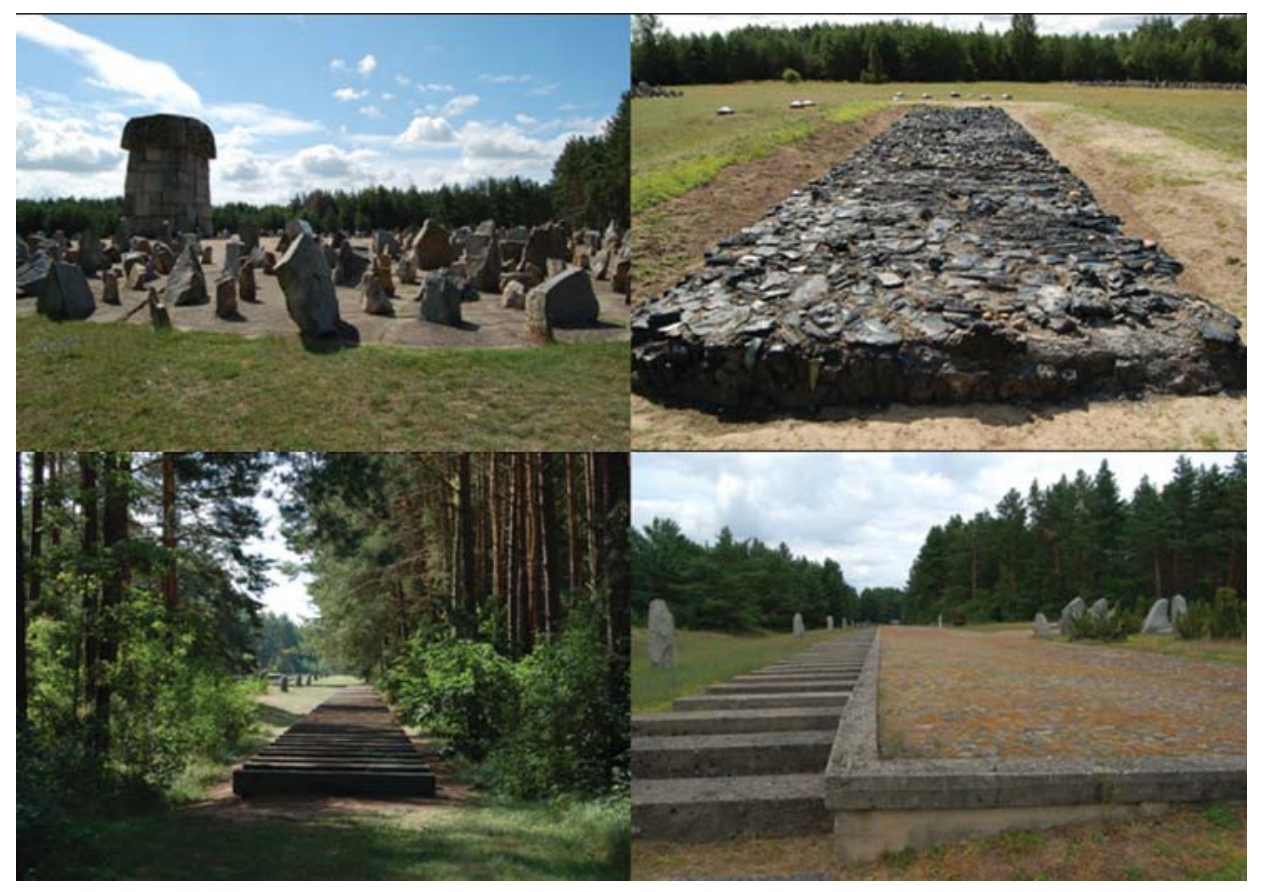

Figure 3 The memorials at the former extermination camp at Treblinka: the memorial in the central area of the former extermination camp (top left), the symbolic cremation pit (top right), the symbolic railway line (bottom left) and the symbolic railway platform (bottom right) (author's own photographs).

A review of the historical evidence suggested that this was unlikely to be the case; photographs of the site after the war show human remains littering the landscape, whilst aerial images and other documentary sources suggest that the total eradication of the structures was highly unlikely (Sturdy Colls, 2011). Consequently, the afore- mentioned methodology was implemented at Treblinka with the aim of determining whether any remnants of Treblinka survive below the ground. Specifically, the project focused on determining the extent of the camp, and the nature and location of the structural foundations and burials contained within it.

Corroboration of the survey results with historical information demonstrated that the current memorial incorrectly demarcates the 
boundary of the camp and that it was much bigger than is shown on the ground. Over one hundred features, including building foundations, pits, and earthworks were identified, clearly demonstrating that the camp was levelled as opposed to completely destroyed, and that, contrary to historical accounts, several archaeological features survive below the ground. These findings clearly demonstrate how even purportedly 'well-known' sites remain unrecorded and misunderstood, with the physical evidence of their existence having been allowed to pass into anonymity in favour of a reliance on historical sources. The use of non-invasive methods allowed this site to be examined appropriately for the first time in accordance with Halacha Law and prevented any disturbance to any human remains present. Concerns over the latter, and the potential implications of the research, are reflected in the fact that it took almost two years to obtain permission from the Chief Rabbi of Poland and the museum authorities for this survey. Preexisting perceptions of archaeology as being destructive had to be overcome, concerns of the local community and the diverse range of visitors to the site had to be addressed, and long-standing perceptions of the site as having been destroyed were challenged. The use of the non-invasive methods has paved the way for a long-term collaboration with the Muzeum Walki i Męczeństwa w Treblince and has opened up the opportunity for excavations away from probable burials.

\section{Alderney, the Channel Islands}

But, of course, the Holocaust was not solely an Eastern European phenomena and several smaller, less well-known sites exist throughout Europe that have remained unrecorded and, in some cases, are not widely known about. In order to explore the archaeology of the Holocaust in Western Europe and to assess both the breadth of physical remains and attitudes towards them, Alderney, in the Channel Islands, was selected for study (Figure 4). During the Second World War, it was occupied by the Germans and housed the only SS camp on British soil, alongside several labour camps at which thousands of individuals lived, worked, and died (Saunders, 2005). Yet, the history of the Occupation did not end with the liberation of the island and, since 1945, various groups have attempted to shape the perceptions of events. Such efforts have been influenced by politics, fear, and cultural affiliation, and have resulted in the emergence of several 'collective memories' that have similarly been altered and diversified over the past seven decades. Whilst there have been some attempts over the last sixty years by British historians to highlight the impact of the Nazi persecution 'on our own doorstep', as it were, there have been no attempts to explore the potential of archaeological work to fill gaps in our knowledge, something which seems particularly pertinent given the recent developments in conflict archaeology in the UK (Figure 5). Questions 
still remain, in particular, about where the vast number of victims were buried.

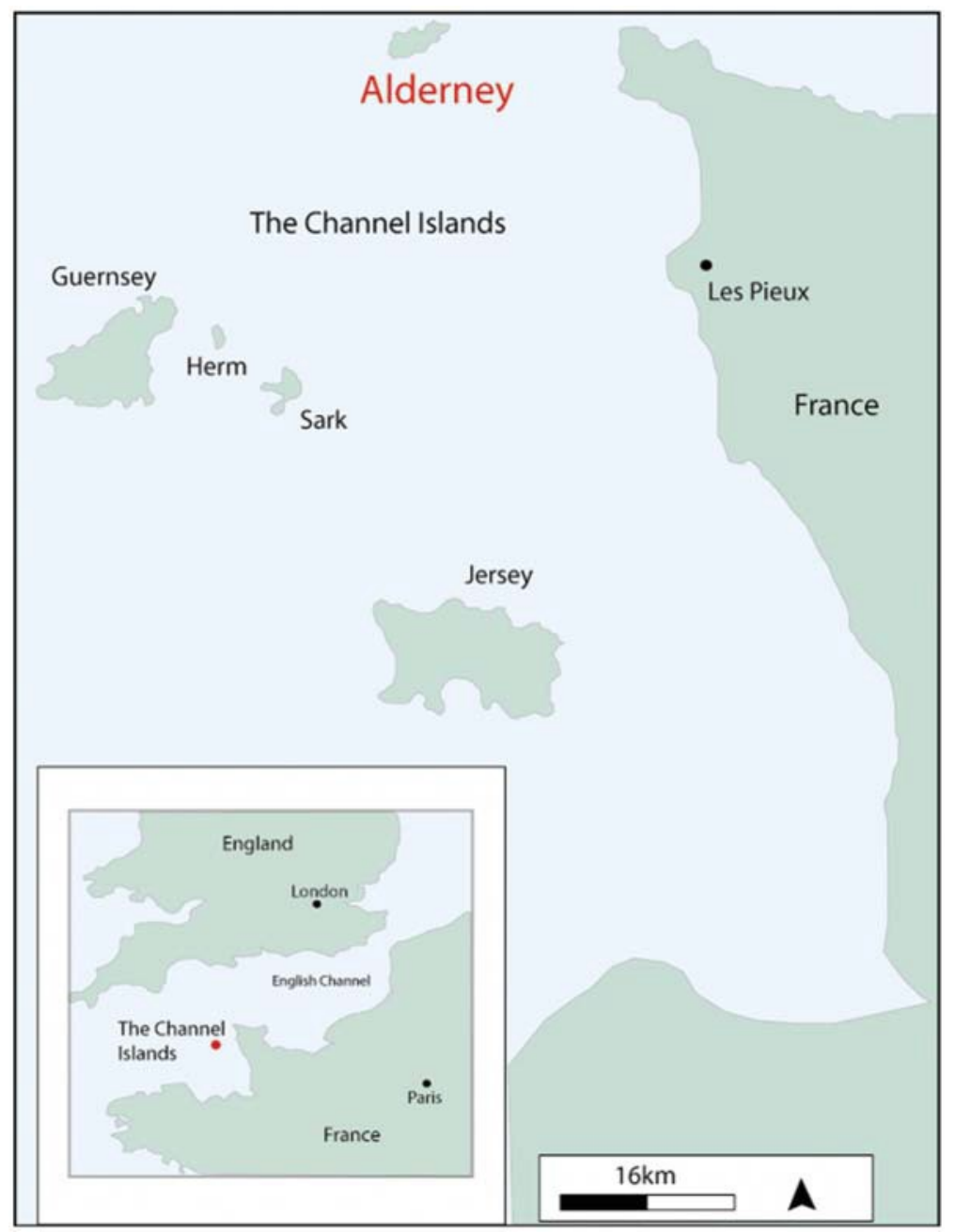

Figure 4 Location plan of Alderney.

The suggestion of fieldwork as part of this project was met with some suspicion, given so-called 'sensationalist' approaches to this period in the past (Freeman-Keel, 1995; Steckoll, 1982) and, in particular, there was a desire by the local community to detach the events on Alderney from the events of the Holocaust. Although there was a general interest in recording the fortifications and other structural remains of the Occupation, there was a marked reluctance to support work examining the camps or potential grave sites. Such problems were overcome by collecting data of value to the local historical society alongside geophysical and topographic surveys of 
the latter. Therefore, during the first season of fieldwork, over one hundred sites were recorded on the SMR, whilst a potential burial site and previously unidentified surviving structures at one of the labour camps were identified. The non-invasive methods, although not required for religious purposes at this site, served a different purpose. Having been deemed less intrusive than excavation, they removed the need to both physically and metaphorically dig up painful memories of the past and allowed the scientific basis of the research to be clearly demonstrated to the local community.
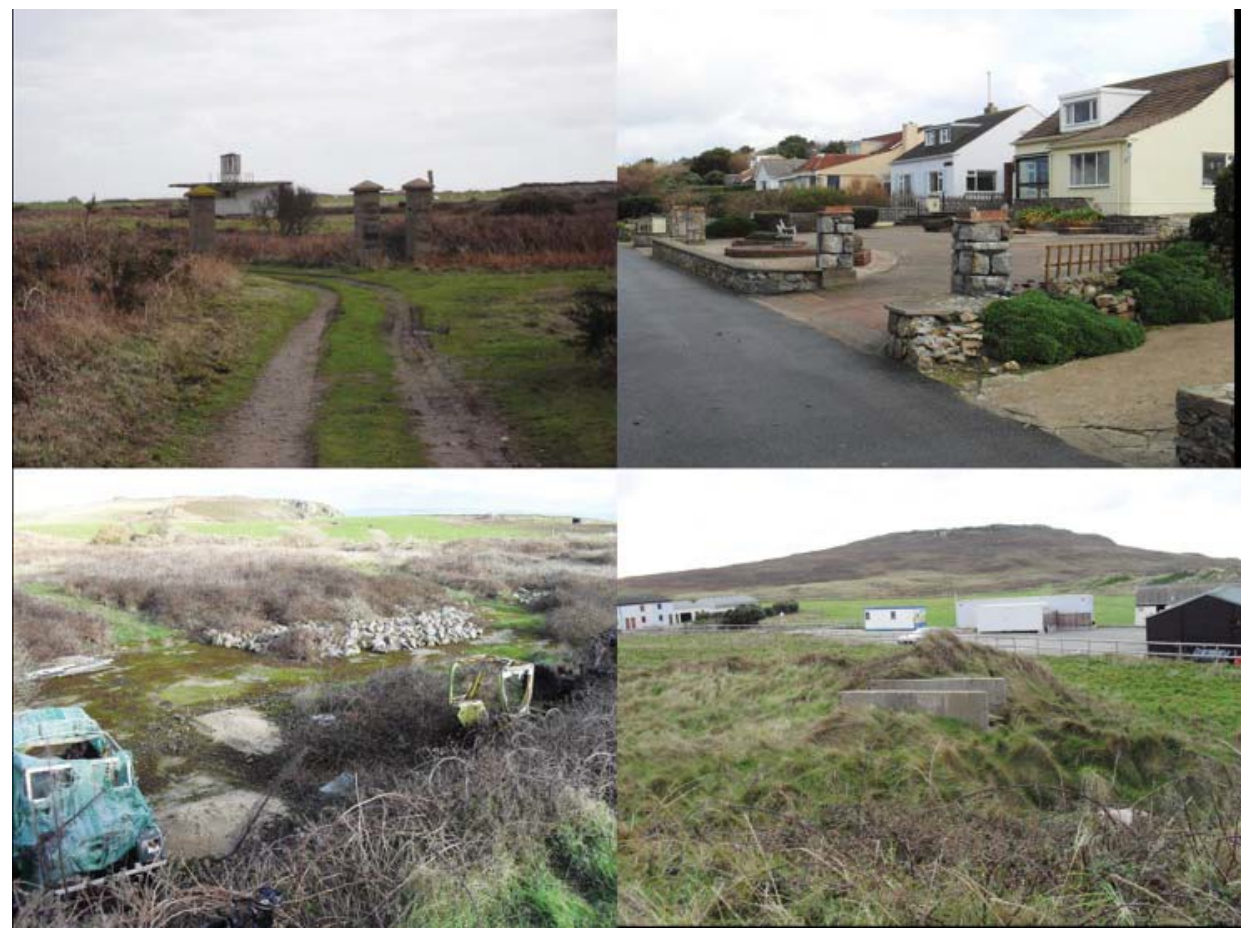

Figure 5 The current condition of the four labour camps on Alderney: Lager Sylt (top left), Lager Helgoland (top right), Lager Borkum (bottom left) and Lager Norderney (bottom right) (author's own photographs).

\section{Discussion}

Beyond camps?

These case studies, alongside the findings of other archaeological work undertaken in the past, demonstrate that an entire landscape of the Holocaust survives which has the potential to reveal new insights into the events of this period. Although in the first instance, the two sites above appear completely different in terms of scale, the level of killings 
undertaken, their geographic location, and the degree of knowledge about them, this only serves as a means of further confirming the diversity of the Holocaust.

Studies examining the archaeological remains of the Holocaust to date have in the main focused on the camps. Whilst there is, of course, a risk here of further heighten- ing the widely held belief by the public that the Holocaust revolved solely around such sites, these examinations are crucial in order to further our understanding of this period. As the example of Treblinka demonstrates, there is a need for archaeological evidence to complement and supplement existing histories and, in some cases such as this, it is capable of radically altering perceptions regarding the survivability of remains. Given that Holocaust archaeology has not yet become a recognized discipline in its own right, it is likely that only research at these high-profile sites will generate wider interest and demonstrate to a larger audience the potential of archaeological approaches. Similarly, research on Alderney, a lesser-known site, highlights the diver- sity of sites and acknowledge that similar trends exist throughout Europe. Again, such revelations are likely to invoke acknowledgement to a larger extent.

However, there are many other possible avenues of research in the form of an examination of the diverse range of other sites, aside from the main camps, associ- ated with the Holocaust. Given the fact that these sites remain as the dominant image of the Holocaust, and the fact that post-war surveys almost exclusively focused on these sites, thousands of smaller camps, ghettos, burial sites (mass graves, cremation pits, and cemeteries), prisons, fortifications, execution sites, and administrative build- ings associated with this period remain unrecorded (Czynska, 1982: 47-48). In order to move towards developing a discipline of Holocaust archaeology, it is imperative to recognize the fact that numerous other types of sites exist that have equal, if not greater, potential in some cases, to reveal information about the past. These sites remain as a testament to the suffering of the victims of the Third Reich, equal in terms of value but different in terms of the unique, unexplored insight into events that they can provide compared to studies of the death camps. It is perhaps in relation to these sites, where very little is likely to remain above ground and cultural memory relating to them may have been lost, that archaeology can provide a source of evidence that is more perceptible than the written word.

\section{The landscapes and archaeologies of the Holocaust}

Given that the Holocaust Archaeology is in its infancy, examinations to date have largely been undertaken in isolation, focusing almost exclusively on single sites. However, in the future, instead of viewing sites as isolated entities, there is a need to facilitate inter-site comparison; if this is not 
possible on the same project, then at the very least this should take place between individuals and organizations studying this period. Essentially, what is advocated here is that archaeologists move away from simply considering sites as a collection of structures and associated features but begin to recognize Holocaust sites as landscapes; just as the events of the Holocaust transcended political and geographical boundaries, so too should analyses of the sites relating to it. At micro level, the sites sit within an immediate landscape which influ- enced their location, the ability of the Nazis to carry out extermination and forced labour, and their ability to conceal these crimes. At macro level, such an approach acknowledges the connections between sites through the transportation of prisoners, the movement of individuals or groups of Nazi soldiers and Commandants, the shipping of personal belongings, and products of the labour programme. Treblinka II, for example, forms part of a landscape with Treblinka I; the hundreds of places from which these victims were rounded up; and the Umschlagplatz in Warsaw, where the victims boarded the train to the camp, to name but a few locations. Far from being an isolated island 'laboratory' (Saunders, 2005: 191), Alderney formed part of the wider landscape of the Channel Islands, with Sachsenhausen and Neuengamme, of which it was a sub-camp, and with the various sites from which victims were deported.

Additionally, although surviving and accessible to differing extents, various archaeologies of the Holocaust can also be identified. From the perspective of the victims, the landscapes are ones of suffering, extermination, internment, loss, and fear, whilst Theune (2011) has argued the camps and the material culture found in them represent an archaeology of powerlessness. Additionally, through features such as the Star of David carved into the rock in Alderney (Cohen, 2000), the unburnt bodies buried in cremation pits (Goldfarb, 1987), and the impact of the Treblinka Revolt (Weinstein, 2002), an archaeology of defiance and resistance can be noted. The actions of the perpetrators can also be seen and, thus, the landscapes can be seen as ones of control, oppression, desecration, murder, and conflict (Bernbeck and Pollack, 2007), whilst even the physical architecture of the camps allude to the deception, in the form of camouflage and oppression taking place there.

\section{Conclusion: the need for Holocaust Archaeology}

Irrespective of whether the Holocaust represents a unique event in world history, many of the responses that have been generated by it and its investigation by scholars are without rival. The key issue to be derived from the above discussion is that in many ways the Holocaust is similar to many other genocides and violent acts, in terms of its potential to be investigated archaeologically. However, the fact that the level of investigation of this 
conflict is not comparable with these other events in most countries indicates that further factors have influenced the extent to which it has been studied. This undoubtedly stems from the vast number of countries, groups, and individuals affected, something which presents archaeologists wishing to consider this period with considerable challenges.

It would appear, in light of the various issues faced by archaeologists in the past, that future research will not be possible without a consideration of these deep-rooted issues; irrespective of the theoretical scientific capabilities and advances, it would appear that the practicalities of their implementation will be influenced by ritual beliefs associated with death and burial, and the ever-changing political and societal approaches to this period (Golbert, 2004; Wilson, 2007; Lang, 1999). Indeed, perhaps as Moshenska (2008: 168) has argued, it is better to approach these sites with a 'do not disturb' attitude in order that we are forced to directly consider the ethical demands that we should adhere to as professional researchers addressing conflict.

Archaeological research has the potential to both complement and supplement existing histories of this period; in some cases it will act to reaffirm historical accounts, in others it will reveal information that cannot be derived from documentary evidence; on occasion it may completely alter historical perception, whilst in other instances it will add to knowledge about a particular aspect. Whatever the result, it is not conducive for history and archaeology to be viewed as being competing disciplines; each informs the other and this is particularly important for surveys that focus solely on non-invasive methods. As a general trend in archaeology, the dissipating link with history in favour of an emphasis on scientific methods has been noted (Sauer, 2004: 1). However, particularly when studying conflict, it is imperative that these subject areas unite, drawing on other areas such as conflict studies, forensic science, forensic psychology, geography, and social anthropology, to maximize the information that can be derived about past events.

There is a need to align research into the archaeological remains of the Holocaust with that of other periods. It has been demonstrated that, to date, many investigations of the physical remains of this period have been reactive responses to changing circumstances at the site in question. Not only are these reactive responses often accompanied by a sense of urgency, but often archaeologists are not asked to assist. The nature of the remains are such that this period cannot simply be allowed to fall victim to the pressures of commercial archaeology; we should not wait until it is necessary to 'rescue' these sites, but instead they should be approached 
proactively with a view to extruding their full value. Ongoing work to build a network of practitioners in this field gives hope for the future and the creation of a sub-discipline of Holocaust Archaeology is proposed, not least of all to facilitate debate with regards to the responsibilities we as archaeologists face when considered this period.

The challenge for the future is one of raising awareness; awareness of the value of, and need for, the investigation of the physical remains, in particular the potential of these investigations to contribute to education; awareness of the commemorative value of the remains and the fact that they do survive in various forms; and, finally, awareness that studies which consider the post-abandonment history of the sites in question, when compared to other sites, can reveal the diversity and constantly changing nature of the European Holocaust landscape.

\section{Bibliography}

Abzug, R. H. 1985. Americans and the Liberation of Nazi Concentration Camps. Oxford: Oxford University Press.

Antkowiak, M. 2000. Erinnerungsarbeit und Erkenntnisgewinn. Die Konzentrationslager Ravensbrück und Sachsenhausen im Spiegel der Bodenfunde. Archäologie in Berlin und Brandenburg, 1999: 149-51.

Antkowiak, M. and Völker, E. 2000. Dokumentiert und konserviert. Ein Außenlager des Konzentrationslagers

Sachsenhausen in Rathenow, Landkreis Havelland. Archäologie in Berlin und Brandenburg, 1999: 147-49. Arad, Y. 1987. Betzec, Sobibor and Treblinka: The Operation Reinhard Death Camps. USA: John Wiley \& Sons.

Arad, Y., Gutman, I., and Margaliot, A. eds. 1999. Documents on the Holocaust: Selected sources on the Destruc- tion of the Jews of Germany, Austria, Poland, and the Soviet Union. 8th edn. Lincoln, London, and Jerusalem: University of Nebraska Press.

Artner, G., Farka, C., Hofer, N., and Kreen, M. 2004. Archäologische Untersuchungen im ehemaligen Konzentrationslager von Mauthausen. In: B. Perz, ed. Das Gedächtnis von Mauthausen. Vienna: BM. I, Bundesministerium für Inneres, Referat IV/7/a.

Assendorp, J. J. 2003. KZ Bergen-Belsen. Archäologie in Niedersachsen, $\mathrm{x}(\mathrm{x}): 78-81$. 
Aulich, J. 2007. Memory, What's it Good For? Forced Labour, Blockhouses and Museums in Pas de Calais, Northern France. In: L. Purbrick, J. Aulich, and G. Dawson, eds. Contested Spaces: Sites, Representations and Histories of Conflict. Basingstoke: Palgrave Macmillan, pp. 191-210.

Auschwitz-Birkenau Memorial and Museum. 2010 [accessed 7 April 2011]. Available at: $<$ www.auschwitz.pl $>$.

BABAO (British Association for Biological Anthropology and Osteoarchaeology). 2008. BABAO Code of Ethics for Archaeological Human Remains, [accessed 29 November 2010]. Available at: $<$ http://www.babao.org.uk/ index/ethics-and-standards>.

Babic, J., Cupkovic, T., and Bosiocic, N. 2000. The Application of Remote Sensing and IT in Research of Mass Graves in the System of Jasenovac Ustasha Camps [accessed 2 August 2010]. Available at: <http://www. jasenovac-info.com/projekti/rsgis_jasenovac_eng.pdf $>$.

Baker, F. 1988. History that Hurts: Excavating 1933-1945. Archaeological Review from Cambridge, 7(1): 94-109.

Baxter, I. 2010. The SS of Treblinka. Stroud: The History Press Ltd.

BBC (British Broadcasting Corporation). 2011. Division mars Poland's Smolensk plane crash anniversary [online] [accessed 12 May 2011]. Available at: <http://www.bbc.co.uk/news/world-europe-13025746>.

BBC (British Broadcasting Corporation). 2007. Ukrainian mass Jewish grave found [online] [accessed 19 January 2008]. Available at: $<$ http://news.bbc.co.uk/1/hi/world/europe/6724481.stm>.

Beder, J. 2002. Mourning the Unfound: How Can We Help. Families in Society: The Journal of Contemporary Human Services, 83(4): 400-03.

Beech, J. 2000. The Enigma of Holocaust Sites as Tourist Attractions - the Case of Buchenwald. Managing Leisure, 5(1): 29-41.

Beech, J. 2002. The Differing Development Paths of Second World War Concentration Camps and the Possibility of an Application of a Principle of Equifinality. In: J. Schofield, W. Gray Johnson, and C. M. Beck, eds. Materiél Culture: The Archaeology of Twentieth Century Conflict. One World Archaeology, 44. 
Bernbeck, R. and Pollack, S. 2007. 'Grabe, Wo Du Stehst!' An Archaeology of Perpetrators. In: Y. Hamilakis and P. Duke, eds. Archaeology and Capitalism: From Ethics to Politics. California: Left Coast, pp. 217-31.

Beth Shalom. 2010. The Holocaust Centre [online] [accessed 8 January 2010]. Available at: $<$ http: $/ /$ holocaustcentre. net $>$.

Bevan, B. 1994. A Case To Answer: The Story of Australia's First European War Crimes Prosecution. South Australia: Wakefield Press.

Bezwinska, J. ed. 1973. Amidst a Nightmare of Crime: Manuscripts of Members of Sonderkommando. Oswięcim: State Museum.

Browning, C. 1993. Ordinary Men: Reserve Police Battalion 101 and the Final Solution in Poland. New York: Penguin Book Group.

Bunting, M. 1995. The Model Occupation: The Channel Islands Under German Rule, 1940-45. London: Pimlico.

Cargas, H. J. 1986. Preface. In: L. Shelley, ed. Secretaries of Death. New York: Shengold.

Carman, J. 2005. Against Cultural Property: Archaeology, Heritage and Ownership. London: Gerald Duckworth \& Co.

Carr, G. 2009. Archaeology That Matters. British Archaeology, 104: 18-22.

Cassia, P. S. 2005. Bodies of Evidence: Burial, Memory and the Recovery of Missing Persons in Cyprus. New Directions in Anthropology, 20. Canada: Berghahn Books.

Central Commission for the Investigation of German Crimes in Poland. 1982. German War Crimes in Poland. New York: Howard Fertig.

Cesarani, D. 2005. After Eichmann: Collective Memory and the Holocaust 1961. London: Routledge. Chapman, H. 2003. Landscape Archaeology and GIS. Stroud: Tempus.

Chrostowski, W. 2004. Extermination: Camp Treblinka. London: Valentine Mitchell. Clendinnen, I. 1999. Reading the Holocaust. Cambridge: Cambridge University Press.

CLUE. 2011. The Heritage and Memory of Conflict and War [online] 
[accessed 30 November 2011]. Available at:

$<$ http://home.medewerker.uva.nl/r.vanderlaarse/bestanden/Heritage $\% 20$ and $\% 20$ Memory\%20of\%20War\%201. pdf $>$.

Cohen, S. 2001. Memory Wars and Peace Commissions, Index on Censorship, 30(1): $38-48$.

Commission of the Historians of Latvia. 2001. The Progress Report of Latvia's History Commission: Crimes against Humanity Committed in the Territory of Latvia from 1940 to 1956 during the Occupations of the Soviet Union and National Socialist Germany. Latvia: Commission of the Historians of Latvia. CWGC (Commonwealth War Graves Commission). 2009. Fromelles Blog [online] [accessed 18 October 2010]. Available at: $<\mathrm{http}$ ://www.cwgc.org/fromelles/blog/?p=567>.

Czynska, S. 1982. Mass Executions in Poland in the Period 1939-1945. In: Central Commission for the Investiga- tion of German War Crimes in Poland. German War Crimes In Poland. 2nd edn. New York: Howard Fertig, pp. 47-66.

David, W. 2001. Archäologische Ausgrabungen im ehemaligen Konzentrationslager Dachau. Unpublished thesis. University of Munich.

David, W. 2003. Archäologische Ausgrabungen in der ehemaligen SSSchießanlage bei Heberthausen. Unpublished thesis. University of Munich.

Davies, I. 2000. Teaching the Holocaust: Educational Dimensions, Principles and Practice. London: Routledge. Desbois, P. 2008. The Holocaust by Bullets: A Priest's Journey to Uncover the Truth Behind the Murder of 1.5 Million Jews. Hampshire: Palgrave Macmillan.

Der Spiegel. 2006. Mass grave of young children found in Germany. Der Spiegel [online] 10 March 2006 [accessed 21 June 2007]. Available at: $<\mathrm{http} / / /$ www.spiegel.de/international/0,1518,440544,00.html $>$.

English Heritage. 2003. Twentieth-Century Military Sites: Current Approaches to their Recording and Conserva- tion. Swindon: English Heritage.

Estonian International Commission for Investigation of Crimes Against Humanity. 2006. Estonia 1940-1945: Reports of the Estonian International Commission for the Investigation of Crimes Against Humanity. Tallinn: Estonian Foundation for Investigating Crimes Against Humanity.

Ferenc, M. 2008. Secret World War II Graves in Slovenia. In: P. Jambrek, 
ed. Crimes Committed by Totalitarian Regimes. Crimes and other Gross and Large Scale Human Rights Violations Committed During the Reign of Totalitarian Regimes in Europe: Crossnational Survey of Crimes Committed. Slovenia: Slovenian Presidency of the Council of the European Union, pp. 155-60.

Fiedler, S., Berger, J., Stahr, K., and Graw, M. 2009. Localisation of a Mass Grave from the Nazi Era: A Case Study. In: K. Ritz, L. Dawson and D. Miller, eds. Criminal and Environmental Soil Forensics. London: Springer.

Field. S. 2007. 'No-one has allowed me to cry': Trauma, Memorialisation and Children in Post-Genocide Rwanda. In: L. Purbrick, J. Aulich, and G. Dawson, eds. Contested Spaces: Sites, Representations and Histories of Conflict. Basingstoke: Palgrave, pp. 211-32.

Fonseca, I. 1995. Bury Me Standing: The Gypsies and their Journey. New York: Vintage Books.

France, D. L., Griffin, T. J., Swanburg, J. G., Lindemann, J. W., Davenport, C., Trammell, V., Travis, C. T., Kondratieff, B., Nelson, A., Castellano, K., Hopkins, D., and Adair, T. 1997. Necrosearch Revisited: Further Multidisciplinary Approaches to the Detection of Clandestine Graves. In: W. Haglund and M. H. Sorg, eds. Forensic Taphonomy: The Postmortem Fate of Human Remains. USA: CRC Press, pp. 497-507.

Freeman-Keel, T. 1995. From Auschwitz to Alderney and Beyond. Worcestershire: Seek Publishing.

Friends of Sobibor Remembrance. 2006. Archaeological Research [online] [accessed 21 December 2007]. Available at: $<$ http://www.sobibor.edu.pl/angielska/historia/index.htm>.

Gaffney, C. and Gater, J. 2003. Revealing the Buried Past. Stroud: Tempus Publishing Ltd.

Gaffney, V., Gater, J., Saunders, T., and Adcock, J. 2004, D-Day: Geophysical Investigation of a World War II German Site in Normandy, France. Archaeological Prospection, 11: 121-28.

Garber, Z. 1994. Shoah: The Paradigmatic Genocide. Essays in Exegesis and Eisegesis. Studies in the Shoah, viii.

Lanham, New York and London: University Press of America. 
Gilchrist, R. 2003. Introduction: Towards a Social Archaeology of Warfare, World Archaeology, 35(1): 1-6. Gilead, I. Hamai, Y., and Mazurek, W. 2009. Excavating Nazi Extermination Centres. Present Pasts, 1: 10-39. Glazar, R. 1999. Trap with a Green Fence: Survival in Treblinka. 2nd edn. Illinois: Northwestern University Press.

Golbert, R. 2004. Holocaust Sites in Ukraine: Pechora and the Politics of Memorialization. Holocaust and Genocide Studies, 18(2): 205-33.

Golden, J. 2003. Remembering Chelmno: Heart-wrenching Finds from a Nazi Death Camp. Archaeology, 56(1): 50-54.

Goldfarb, A. quoted in Arad, Y. 1987. Betżec, Sobibor and Treblinka: The Operation Reinhard Death Camps. USA: John Wiley \& Sons.

González-Ruibal, A. 2007. Making Things Public: Archaeologies of the Spanish Civil War. Public Archaeology, 6(4): 203-26.

González-Ruibal, A. 2008. Time to Destroy: An Archaeology of Supermodernity. Current Anthropology, 49(2): 247-79.

Gould, R. A. and Schiffer, M. B. 1981. Modern Material Culture: The Archaeology of Us. New York: Academic Press.

Gross, J. 2004. Critical Remarks Indeed. In: A. Polonsky and J. B. Michlic, eds. The Neighbours Respond: The Controversy Over The Jedwabne Massacre In Poland. Princeton: University Press, pp. 344-70.

Grothe, A. 2006. Erzwungene Dienstleistung. Arbeitslager und Wirtschaftsbetrieb bei Groß Schönebeck, Lkr. Barmin. Archäologie in Berlin und Brandenburg 2006, pp. 10-39.

Gruber, S. and Myers, P. 1995. Survey of Historic Jewish Monuments in Poland: A Report to the United States Commission for the Protection of America's Heritage Abroad. 2nd edn. USA: Commission for the Protection of America's Heritage Abroad.

Guardian, 12 January 2009.

Haglund, W. 2002. Recent Mass Graves: An Introduction. In: W. Haglund and M. H. Sorg, eds. Advances in Forensic Taphonomy: Method, Theory and Archaeological Perspectives. USA: CRC Press, pp. 243-62. 
Harrison, R. and Schofield, J. 2010. After Modernity: Archaeological Approaches to the Contemporary Past. Oxford: Oxford University Press.

Hayes, P. 2003. Auschwitz, Capital of the Holocaust: Review Essay. Holocaust and Genocide Studies, 17(2): 330-50.

Hirte, R. 2000. Offene Befunde. Ausgrabungen in Buchenwald. Zeitgeschichtliche Archäologie und Erinnerung- skultur. Braunschweig: Hinz \& Kunst.

Hunter, J. R. and Cox, M. 2005. Forensic Archaeology: Advances in Theory and Practice. London: Routledge. Hunter, J. R. and Simpson, B. 2007. Preparing the Ground: Archaeology in a War Zone. In: R. Ferllini, ed. Forensic Archaeology and Human Rights Violations. Illinois: Charles C Thomas Pub Ltd, pp. 266-92.

Hunter, J. R., Simpson, B., and Sturdy Colls, C. forthcoming. Forensic Approaches to Buried Remains. London:Wiley.

Huyssen, A. 1994. Monument and Memory in a Postmodern Age. In: J. E. Young, ed. The Art of Memory: Holocaust Memorials in History. Prestel: Munich, pp. 9-17.

Ibel, J. 2002. Konzentrationslager Flossenbürg: Ausgrabungen und Funde. Das Archäologische Jahr in Bayern: 147-49.

International Commission on Missing Persons.2011. [online] [accessed 12 June 2011]. Available at: <www. ic-mp.org >

International Herald Tribune, 14 June 2007.

International Jewish Cemetery Project. 2010. [online] [accessed 29 June 2010]. Available at: $<$ http://www. iajgsjewishcemeteryproject.org/easterneurope/index.html $>$.

International Military Tribunal Nuremberg. 1947. Trial of the Major War Criminals before the International Military Tribunal Nuremberg, 14 November 1945-1 October 1946. [online] [accessed 20 October 2007]. Available at: $<$ http://www.loc.gov/rr/frd/Military_Law/NT_major-warcriminals.html>.

IPN [Institute of National Remembrance]. 2009. [online] [accessed 21 February 2009]. Available at: <www.ipn. gov.pl $>$. 
Irving, D. 2010. [online] [accessed 20 October 2010]. Available at: $<$ http://www.fpp.co.uk/wolfslair $>$.

Isenberg, G. 1995. Zu den Ausgrabungen im Konzentrationslager WittenAnnen. Ausgrabungen und Funde, 40: 33-37.

Jacobs, J. 2004. From the Profane to the Sacred: Ritual and Mourning at Sites of Terror and Violence. Journal for the Scientific Study of Religion, 43(3): 311-15.

Jankauskas, R., Barkus, A., Urbanavièius, V., and Garmus, A. 2005. Forensic Archaeology in Lithuania: the Tuskulënai Mass Grave. Acta Medica Lithuania, 12(1): 70-74.

Jasinski, M. 2011. WWII and the Atlantic Wall in Norway: Landscapes of Supremacy and Slave Labour. 4 August 2011. [Lecture] Atlantic Wall Research Group Workshop, McDonald Institute, Cambridge.

Kellerman, N. P. F. 2001. The Long-term Psychological Effects and Treatment of Holocaust Trauma. Journal of Loss and Trauma, 137(6): 197-217.

Kleiman, Y. and Springer-Aharoni, N. eds. 1995. The Anguish of Liberation: Testimonies of 1945. Israel: Yad Vashem Publications.

Klimesch, W. 2002. Veritatem dies aperit! Vernichtet — Vergraben Vergessen. Archäologische Spuren im Schloss Hartheim, Jahrbuch des Oberösterreichischen Musealvereines, 147(1): 411-34.

Knischewski, G. and Spittler, U. 2007. Competing Pasts: A Comparison of National Socialist and German Democratic Republic Remembrance in Two Berlin Memorial Sites. In: L. Purbrick, J. Aulich, and G. Dawson, eds. Contested Spaces: Sites, Representations and Histories of Conflict. Basingstoke: Palgrave Macmillan, pp. 318-27.

Kola, A. 2000. Betzec: The Nazi Camp For Jews in the Light of Archaeological Sources, Excavations 1997-1999. Warsaw and Washington: The Council for the Protection of Memory of Combat and Martyrdom.

Kola, A. 2001. Badania archeologiczne terenu byłego obozu zagłady Żydów w Sobiborze. Przeszłość i Pamięć. 
Biuletyn Rady Ochroni Pamięci Walk i Męczeństwa, 4: 115-22.

Krondorfer, B. 2008. Is Forgetting Responsible: Holocaust Remembrance and the Task of Oblivion. Journal of Religious Ethics, 36(2): 233-67.

Kushner, T. 2006. Holocaust Testimony, Ethics, and the Problem of Representation. Poetics Today, 27: 275-95.

Kuwałek, R. 2008. From Lublin to Betzec: Traces of Jewish Presence and the Holocaust in South-Eastern Part of the Lublin Region. Lublin: Ad Rem.

Lang, B. 1999. Between History and Memory: The Future of the Holocaust. USA: Cornell University Press. Lang, B. 2000. Holocaust Representation: Art within the Limits of History and Ethics. Baltimore: JHU Press. Lennon, J. and Foley, M. 2000. Dark Tourism. Padstow: Thomson.

Levy, M. N. 1992. Jewish Law and the Holocaust. University of Toronto Faculty of Law Review, p. 241.

Lilley, J. M., Stroud, G., Brotherwell, D. R. and Williamson, M. H. 1994. The Jewish Burial Ground at Jewbury. York: Council for British Archaeology.

Lisle, D. 2007. Encounters with Partition: Tourism and Reconciliation in Cyprus. In: L. Purbrick, J. Aulich, and G. Dawson, eds. Contested Spaces: Sites, Representations and Histories of Conflict. Basingstoke: Palgrave Macmillan.

Lowenthal, D. 1985. The Past is a Foreign Country. Cambridge: Cambridge University Press. Łukaszkiewicz, Z. 1946. Obóz straceń w Treblince. Warsaw: Państwowy Instytut Wydawniczy. Mant, A. K. 1950. A Study of Exhumation Data. Unpublished thesis, London University.

Marquez Grant, N. and Fibiger, L. 2010. The Routledge Handbook of Archaeological Human Remains and Legislation. Routledge: London.

Matthews, C. N. 2009. Review Essay: Is Archaeology Political? Transformative Praxis Within and Against the Boundaries of Archaeology. The Public Historian, 31(2): 79-90.

McDavid, C. 2002. Archaeologies that Hurt, Descendants that Matter: a Pragmatic Approach to Collaboration 
in the Public Interpretation of African-American Archaeology. World Archaeology, 34(2): 303-14. Melmed LeHoil, Yoreh Deah 114:2 (Rabbi Dovid Tzvi Hoffman, Germany 1843-1921).

Mémorial de la Shoah. 2007. The Mass Shooting of Jews in Ukraine 19411944: The Holocaust by Bullets [online] [accessed 20 June 2008]. Available at: $\quad<$ http://www.memorialdelashoah.org/upload/minisites/ukraine/en/en_ exposition $1 . h t m>$.

Meng, J. 2010. From Destruction to Preservation: Jewish Sites in Germany and Poland after the Holocaust. Bulletin of the GHI, 46: 45-59.

McGuire, R. 2008. Archaeology as Political Action. California Series in Public Anthropology. California: University of California Press.

Ministry of Foreign Affairs. 2008. From the Pages of Polish History: Nazi German Camps on Polish Soil During World War II. Poland: Ministry of Foreign Affairs.

Moeller, R. 2006. On the History of Man-Made Destruction: Loss, Death, Memory, and Germany in the Bombing War. History Workshop Journal, 161: 103-34.

Moshenska, G. 2008. Ethics and Ethical Critique in the Archaeology of Modern Conflict. Norweigan Archaeological Review, 41(2): 159-75.

Novick, P. 1999. The Holocaust in American Life. Boston and New York: Houghton Mifflin Harcourt. O'Neil, R. 1998. Bełżec- the Forgotten Death Camp. East European Jewish Affairs, 28(2): 49-62.

O'Neil, R. and Tregenza, M. 2006. Archaeological Investigations: A Review By Historians [online] [accessed 17 October 2007]. Available at: $<$ www.holocaustresearchproject.org/ar/modern/archreview.html $>$.

Paperno, I. 2001. Exhuming the Bodies of Soviet Terror. Representations, 45: $89-118$.

Paris, A, 2011. The KL Stutthof Archaeological Resources Protection and Preservation Program: Site Assessment Report [online] [accessed 12 May 2011]. Available at: <http://stutthof.pl/english/node/147>.

Pawlicka-Nowak, Ł. 2004a. Archaeological Research in the Grounds of the Chełmno-on-Ner Extermination Center. In: Ł. Pawlicka-Nowak, ed. The 
Extermination Center for Jews in Chetmno-on-Ner in the Light of Latest Research. Symposium Proceedings 6-7 September 2004. Konin: District Museum.

Pawlicka-Nowak, Ł. 2004b. Archaeological Research in the grounds of the Chełmno-on-Ner Former Extermina- tion Center. In: Ł. Pawlicka-Nowak, ed. Chetmno Witnesses Speak. Konin and Lódź: The Council for the Protection of Memory of Combat and Martyrdom in Warsaw.

Payne, S. 2009. Is it Right to Excavate and Study Human Remains? Reexamining the Issues of Jewbury. The Archaeologist, 72: 42-43.

Perera, C. and Briggs, C. 2008. Guidelines for the Effective Conduct of Mass Burials Following Mass Disasters: Post-Asian Tsunami Disaster Experience in Retrospect. Forensic Science and Medical Pathology, 4: 1-8.

Pilichowski, C. 1980. No Time Limit For These Crimes. Warsaw: Interpress.

Pollard, T. 2007. Burying the Hatchet? The Post-Combat Appropriation of Battlefield Spaces. In: L. Purbrick,

J. Aulich, and G. Dawson, eds. Contested Spaces: Sites, Representations and Histories of Conflict. Basingstoke: Palgrave Macmillan, pp. 121-45.

Polonsky, A. and Michlic, J. B. 2004. The Neighbours Respond: The Controversy over the Jedwabne Massacre In Poland. Princeton: Princeton University Press.

Profatilov, I. 1945. Evidence on the Killing of Jews in Kharkov: On the Mass Shooting of Jews by the German Murderers in the Drobitzki Valley. In: Y. Arad, I. Gutman, and A. Margaliot, eds. 1999. Documents on the Holocaust: Selected Sources on the Destruction of the Jews of Germany, Austria, Poland, and the Soviet Union. 8th edn. Lincoln, London, and Jerusalem: University of Nebraska Press, pp. 421-25.

Pullan, W. 2007. Contested Mobilities and the Spatial Topography of Jerusalem. In: L. Purbrick, J. Aulich, and G. Dawson, eds. Contested Spaces: Sites, Representations and Histories of Conflict. Basingstoke: Palgrave Macmillan, pp. 172-79.

Purbrick, L. Aulich, J., and Dawson, G. eds. 2007. Contested Spaces: Sites, Representations and Histories of Conflict. Basingstoke: Palgrave 
Macmillan.

Pyburn, K. 2009. Practising Archaeology — As if it Really Matters. Public Archaeology, 8(2-3): 161-75.

Raalte, E., Van IJzendoorn, M. H., and Bakermans-Kranenburg, M. J. 2007. Quality of Care After Early Childhood Trauma and Well-Being in Later Life: Child Holocaust Survivors Reaching Old Age. American Journal of Orthopsychiatry, 77(4): 514-22.

Rahtz, P. A. 1995. The Incomparable Hallmark of the Divine Image. Antiquity, 69(1): 196-200.

Rosensaft, M. Z. 1979. The Mass-Graves of Bergen-Belsen: Focus for Confrontation. Jewish Social Studies, 41(2): 155-86.

Roth, J. K. 2005. Ethics During and After the Holocaust: In the Shadow of Birkenau. London: Palgrave. Rzeźniak, M. 2007. Rotunda Zamojska/The Zamosc Rotunda. Przewodnik/The Guide Book. Zamość: Muzeum Zamojskie.

Sauer, E. W. 2004. Archaeology and Ancient History: Breaking Down the Boundaries. Abingdon: Psychology Press.

Saunders, A. 1998. The Defence of Britain Project. In: J. Schofield, ed. Monuments of War: The Evaluation, Recording and Management of TwentiethCentury Military Sites. London: English Heritage, pp. 7-9.

Saunders, N. 2001. Excavating Memories: Archaeology and the Great War, 1914-2001. Antiquity, 76: 101-08. Saunders, P. 2005. The British Channel Islands Under German Occupation 1940-45. Jersey: Jersey Heritage Trust.

Schmitt, S. 2002. Mass Graves and the Collection of Forensic Evidence: Genocide, War Crimes and Crimes against Humanity. In: W. Haglund and M. H. Sorg, eds. Advances in Forensic Taphonomy: Method, Theory and Archaeological Perspectives. USA: CRC Press.

Schofield, J. ed. 2004. Modern Military Matters. Studying and Managing the Twentieth Century Defence Heritage in Britain: A Discussion Document. York: Council for British Archaeology.

Schute, I. and Wijnen, J. A. T. 2010. Archeologisch Onderzoek in Eenchuldig Lanschap: Concentratiekamp Amersfoort. RAAP-Rapport 
2197. Weesp: RAAP.

Short, G. and Reid, C. A. 2004. Issues in Holocaust Education. Aldershot: Ashgate Publishing Ltd.

Skinner, M., York, H. P., and Connor, M. A. 2002. Postburial Disturbance of Graves in Bosnia-Herzegovina. In: W. Haglund and M. H. Sorg, eds. Advances in Forensic Taphonomy: Method, Theory and Archaeological Perspectives. USA: CRC Press.

Smith, S. D. 2007. Forgotten Places. The Holocaust and the Remnants of Destruction: A Photographic Essay. Nottingham: Quill.

Smith, L. and Akagawa, N. 2008. Intangible Heritage. Oxon: Routledge.

Sofaer Derevenski, J. 2000. Children and Material Culture. London and New York: Routledge. Steckoll, S. 1982. The Alderney Death Camp. London, Toronto, Sydney, and New York: Granada. Sturdy Colls, in prep. Holocaust Archaeology.

Sturdy Colls, C. 2011. Holocaust Archaeology: Archaeological Approaches to Landscapes of Nazi Genocide and Persecution. PhD thesis, University of Birmingham.

Susa, E. 2007. Forensic Anthropology in Hungary. In: M. Brickley and R. Ferlini, eds. Forensic Anthropology: Case Studies from Europe. USA: Charles C Thomas Publisher.

Sweibocka, T. ed. 1995. Auschwitz: A History in Photographs. 2nd edn. Warsaw: John Wiley \& Sons.

Theune, C. 2010. Historical Archaeology in National Socialist Concentration Camps in Central Europe. Historische Archäologie, 2: 1-13.

Theune, C. 2011. Archaeology and Remembrance. Archaeological Research at Former Concentration Camps. 19 May. [lecture] McDonald Institute, Cambridge.

Treblinka: Materiaty dotyczace realizacji Mauzoleum Ofiar Obozu Zagłady $w$ Treblince. 2011. Directed by K. Radecka [DVD] Gdańsk: Gdańsk University.

Tsokos, M., Lessig, R., Grundmann, C., Benthaus, S., and Peschel, O. 
2006. Experiences in Tsunami Victim Identification. International Journal of Legal Medicine, 120: 185-87.

Under Sobibor. 2008. [online] [accessed 12 July 2008]. Available at: $<$ www.undersobibor.org $>$.

US Commission for the Preservation of America's Heritage Abroad. 2005. Jewish Cemeteries, Synagogues and Mass Grave Sites in the Ukraine [online] [accessed 3 September 2007]. Available at: <http://www. heritageabroad.gov.uk/reports/doc/survey_ukrain_2005.pdf $>$.

US Holocaust Memorial Museum. 2009. [online] accessed 12 January 2010]. Available at: <http://www.ushmm. org/maps/>.

Weiss, A. 2003. A Monumental Failure at Belzec [online] [accessed 21 September 2007]. Available at: <http:// www.hir.org/amcha/belzec.html>.

Wiernik, J. 1944. A Year in Treblinka: An Inmate who Escaped Tells the Day-to-day Facts of One Year of his Torturous Experience. New York: American Representation of the General Jewish Workers' Union of Poland.

Williams, E. D. and Crews, J. D. 2003. From Dust to Dust: Ethical and Practical Issues Involved in the Location, Exhumation, and Identification of Bodies from Mass Graves. Croatian Medical Journal, 44(3): 251-58.

Williams, H. and Williams, E. J. L. 2007. Digging for the Dead: Archaeological Practice as Mortuary Commemoration. Public Archaeology, 6(1): 47-63.

Wilson, R. J. 2007. Archaeology on the Western Front: The Archaeology of Popular Myths. Public Archaeology, 6(4): 227-41.

Wright, R., Hanson, I., and Sterenberg, J. 2005. The Archaeology of Mass Graves. In: J. R. Hunter and M. Cox, eds. Forensic Archaeology: Advances in Theory and Practice. London: Routledge.

Yad Vashem 2009. [online] [accessed 3 October 2009]. Available at: $<\mathrm{http} / /$ www1.yadvashem.org/yv/en/education/learning_environments/sites map.asp $>$.

Yahad In-Unum. 2011. [online] [accessed 3 October 2009]. Available at: $<\mathrm{http}$ ://www.yahadinunum.org>. Young, J. E. ed. 1994. The Art of Memory: Holocaust Memorials in History. Munich: Prestel. 
Zertal, D. 2010. Israel's Holocaust and the Politics of Nationhood. Cambridge: Cambridge University Press.

Zubrzycki, G. 2006. The Crosses of Auschwitz: Nationalism and Religion in Post-Communist Poland. Chicago: University of Chicago Press.

\section{Notes on contributor}

Caroline Sturdy Colls is a Lecturer in Forensic Investigation at Staffordshire Univer- sity, teaching forensic archaeology, identification of human remains, and various aspects of crime scene investigation. She graduated from the University of Birming- ham with a BA (Hons) Archaeology and Ancient History in 2007 and an MPhil (B) in Archaeological Practice in 2008 and has completed her $\mathrm{PhD}$, entitled 'Holocaust Archaeology: Archaeological Approaches to Landscapes of Nazi Genocide and Persecution'. In particular, she has developed a non-invasive methodology to allow the scientific, ethical, and religious aspects associated with studies of this period to be upheld. She is currently managing on-going research projects in Poland and Alderney, and is involved in a number of other collaborative projects with colleagues throughout Europe. She is a practising forensic archaeologist, undertaking consul- tancy for UK police forces on the search and recovery of buried remains. She has been applying forensic archaeological methods to the investigation of cold cases and socio-historic conflicts. She is co-author of a forthcoming book entitled Forensic Approaches to Buried Remains, and is the Treasurer of the Forensic Archaeology Special Interest Group, under the auspice of the Institute for Archaeologists.

Correspondence to: Dr. Caroline Sturdy Colls, Faculty of Sciences, Staffordshire University, Sciences Centre, Leek Road, Stoke-on-Trent, ST4 2DF, UK. Email: c.sturdy-colls@staffs.ac.uk. 